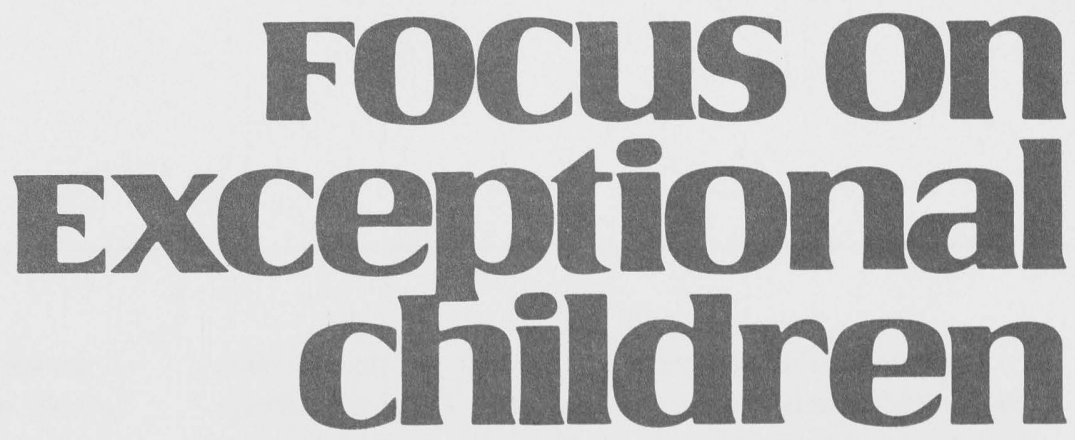

\title{
Rethinking Secondary School Programs for Students with Learning Disabilities
}

\section{Naomi Zigmond}

Nearly 15 years have passed since enactment of the Education for All Handicapped Children Act (PL 94-142) and the federal government's assurance of a free and appropriate public education for students with handicaps. During that time the numbers of students served in special education programs has grown to nearly 4.5 million, an increase of $21 \%$ over $1976-77$ counts.

Nowhere has the change in size and scope of special education services been more astounding than in the field of learning disabilities (LD). In the 15 years just passed, the numbers of students identified and served in programs for students with learning disabilities has increased by more than $145 \%$. Every state in the nation has seen an increase in service rates in learning disabilities, with the service rates for students of secondary school age accounting for the greatest change. According to the Eleventh Annual Report to Congress (U.S. Department of Education, 1989) 1,025,010 students 12 to 17 years old have been diagnosed as LD and are receiving special education services.

Before passage of PL 94-142, only a small body of literature specifically addressed the characteristics and needs of adolescents with learning disabilities. It is not that learning disabilities were not thought to exist in adolescents and young adults. Indeed, early descriptions of students with dyslexia and related learning disabilities often included case studies of students in the age range of 12 to 21 years (see Critchley, 1964, pp. ix-xi; Johnson \& Myklebust, 1967, pp. 229-232). But secondary school-aged students with learning disabilities were not considered a distinct population with distinct characteristics and programming needs.

Dr. Zigmond is affiliated with the Department of Instruction and Learning, University of Pittsburgh. 
The tide certainly has turned in the past decade and a half. Since 1975, there has been an enormous expansion of concern for, programming with, research on, and literature about students with learning disabilities in high school, and in the process of moving from school to work or further education. After reviewing past service delivery models and efficacy data, two models of services are proposed here. These models incorporate four components that I believe have potential for meeting the goals of a meaningful high school education and a smooth transition to life beyond school, each with important implications for staffing and teacher preparation as well as for general school policy and administration.

\section{EARLY SERVICE DELIVERY MODELS: THE CSDC EXPERIMENTS}

In the mid 1970 s special education programs for students with learning disabilities at the elementary level were commonplace, but few school districts provided programs for stu-

\section{FOCus on Exceptional children}

ISSN 0015-511X FOCUS ON EXCEPTIONAL CHILDREN (USPS 203-360) is published monthly except June, July, and August as a service to teachers, special educators, curriculum specialists, administrators, and those concerned with the special education of exceptional children. This publication is annotated and indexed by the ERIC Clearinghouse on Handicapped and Gifted Children for publication in the monthly Current Index to Journals in Education (CIJE) and the quarterly index, Exceptional Children Education Resources (ECER). It is also available in microfilm from Xerox University Microfilms, Ann Arbor, MI. Subscription rates: Individual, \$27 per year; institutions, $\$ 36$ per year. Copyright (c) 1990, Love Publishing Company. All rights reserved. Reproduction in whole or part without written permission is prohibited. Printed in the United States of America. Second class postage is paid at Denver, Colorado. POSTMASTER: Send address changes to:

$$
\begin{aligned}
& \text { Love Publishing Company } \\
& \text { Executive and Editorial Office } \\
& 1777 \text { South Bellaire Street } \\
& \text { Denver, Colorado } 80222 \\
& \text { Telephone (303) } 757-2579
\end{aligned}
$$

Edward L. Meyen

University of Kansas
Glenn A. Vergason Georgia State University

Richard J. Whelan University of Kansas Medical Center
Carolyn Acheson Senior Editor dents with learning disabilities in secondary schools. After PL 94-142 was passed in 1975, schools were legally mandated to provide appropriate services for students with learning disabilities until graduation from high school or until age 21 (or age 25 in some states) and school districts undertook widespread efforts to develop secondary-level special education programs.

Of course, school authorities were responding not only to the mandate. Parents and educators had a growing realization that, despite the emphasis on, and the optimism associated with, early intervention efforts, the learning difficulties of students with learning disabilities were not being ameliorated in the elementary grades. Many of these youngsters were leaving elementary school special education programs poorly equipped in the academic skills necessary for success in high school. Furthermore, many students were being identified as learning disabled in the intermediate and middle school grades and were entering high school having had no opportunity for early intervention.

Most of the new approaches to secondary school services for students with learning disabilities grew out of the network of Child Service Demonstration Centers (CSDCs) funded by the Bureau of Education for the Handicapped $(\mathrm{BEH})$ between 1975 and 1977. These included:

1. The Parallel Alternate Curriculum for Secondary Classrooms, developed in Arizona.

2. Strategies to Increase Learning Efficiency Among LD Adolescents, developed in Kansas.

3. The Model Resource Room Project, developed in Michigan.

4. The Oklahoma Child Service Demonstration Center.

5. The Synergistic Education Model: A Comprehensive Plan for Learning Disabled, developed in Texas.

6. The Pittsburgh Child Service Demonstration Center (see Riegel \& Mathey, 1980).

These CSDC models had in common a commitment to the concept of mainstreaming, consideration of the students' learning and behavioral characteristics, a focus on students with mild to moderate learning disabilities, attention to characteristics of the high school settings in which the students operated, design of specific, replicable methodologies of instruction, incorporation of motivational strategies, and attention to the importance of generalization and maintenance of skills.

But the CSDC models also differed on a number of important dimensions. For example, in the Kansas model the primary focus for change was the student; in the Arizona model 
it was the school environment; in the remaining models both the students and the environment were targets for change efforts. A fundamental philosophy of the Kansas model was that students with learning disabilities must and can learn to become autonomously successful in academic and social environments, even if those environments often seem hostile and resistant. In contrast, developers of the Arizona model believed that students' academic and behavioral deficiencies could not be ameliorated and that students with learning disabilities would be successful in high school only if mainstream content demands (i.e., the environment and curriculum) could be modified to accommodate the disabilities and deficiencies of the students. The Oklahoma, Michigan, Texas, and Pittsburgh models incorporated strategies to promote change both in student behaviors and in mainstream curricular and instructional processes.

Another dimension upon which the CSDC models varied was the setting in which primary interventions were designed to take place. For example, in the Kansas model primary interventions were designed for the resource room setting. In the Arizona model mainstream content subject classes were the target sites for intervention. In the Oklahoma, Michigan, Texas, and Pittsburgh models interventions were designed for both resource room and mainstream class settings.

Some of the CSDC models emphasized direct services to students, whether by the special education resource room teacher (Kansas) or by the mainstream teacher (Arizona). Others featured a combination of direct and indirect services to students through consultation to mainstream teachers (Oklahoma, Michigan, Texas, and Pittsburgh).

The CSDC models also varied significantly with regard to instructional emphasis. The Kansas model emphasized instruction in a wide range of learning strategies (i.e., techniques, principles and rules that would enable the student to learn independently and to solve problems) in lieu of basic skills instruction. The Oklahoma model combined remediation of academic skill deficiencies with training in compensatory strategies. The Texas model combined reading remediation to promote comprehension and vocabulary development with a social-behavioral program to build stronger selfconcepts, develop communication skills, foster selfresponsibility, and teach problem solving strategies. The Pittsburgh model provided for basic skills remediation in reading or mathematics along with instruction in nonacademic skills (self-management, social, organizational, and study skills) that the developers believed were necessary for survival both within and outside the school setting.

Federal funding for the CSDC network ended within 2 years, although pressures on school districts to provide sec- ondary school programs intensified. Forced to move quickly, school districts developed a plethora of hastily conceived adaptations of the CSDC models without the funding for technical support that might have ensured adequate implementation. By 1979 the most common service delivery model for secondary school-aged students with learning disabilities was simply an adaptation of the elementary school resource room-primary placement in mainstream classes with part-time instruction provided by special education personnel (Deshler, Lowrey, \& Alley, 1979).

Most of these resource room programs continued the elementary school emphasis on remediation of basic skills (reading, writing and mathematics); the goal was competence in basic literacy and numeracy. But many resource room teachers also provided instruction to LD students designed to help them achieve better grades in mainstream content subject classes, assisted students in completing regular class assignments, offered drill exercises to prepare students for an upcoming test in a mainstream class, arranged with mainstream content subject teachers to allow for administration of chapter tests or final exams by the resource teacher in the resource room (thus permitting more time for oral presentation of test items), and arranged for students to tape mainstream class lectures in lieu of taking notes. For many LD teachers and their students these additional "tutorial" activities gradually consumed all of the resource room time, and little time was left for remedial instruction, or for the other curricular elements introduced in the CSDCs, such as social or survival skills or learning strategies.

\section{EVIDENCE OF PROGRAM EFFECTIVENESS}

\section{Dropout Rate}

Special education programs are supposed to be nurturing, sustaining, and personalized, somewhere in the school system where students with handicaps can find special education teachers who care, who explain the importance of sustaining an interest in high school, who make learning relevant and accessible, and who help students to succeed. These are the very elements that have also been associated with successful dropout prevention programs (see Wehlage, Rutter, Smith, Lesko, \& Fernandez, 1989) —attention to individual student needs, small student-teacher ratio, more opportunities for personal counseling, and utilization of individualized and diversified instructional strategies. So, if high school programs for students with learning disabilities are implemented appropriately, we should expect LD students to be staying in school. 
My colleagues and I spent 6 years working with special education and mainstream administrators, supervisors, and teachers in a large urban school district, to refine implementation of the Pittsburgh CSDC model of secondary school services for students with learning disabilities. By 1981 the model program had been in place long enough so that 52 students who had entered high school in 1977-78 as ninth graders and had been placed in the LD program should have been in 12th grade. We set out to document the progress of these 52 adolescents (see Levin, Zigmond, \& Birch, 1985). We expected to find the students in 11 th or 12 th grade, some fully mainstreamed, some still being served in special education resource rooms, all showing improved basic skills and getting ready for the world of work. Instead, as far as we could determine, $47 \%$ of the learning disabled students had dropped out of school, a rate far in excess of the $36 \%$ dropout rate for nonhandicapped students reported by the host school district for the same time period.

The Levin et al. (1985) sample was very small, but the findings deeply troubled us. We had worked hard with the school district to develop a secondary school LD program that was sensible and meaningful. We had taught teachers how to help students make it in their mainstream classes. We had trained one special education teacher to function in a consulting teacher role to help students with learning disabilities and their mainstream teachers alike. We had data to indicate that a large percentage of the students with learning disabilities who came to school were earning passing grades (Zigmond, Levin, \& Laurie, 1985). Disappointed to discover that students for whom we had designed this "special" education were abandoning it, we embarked on a second study to verify our original dropout findings.

Zigmond and Thornton (1985) located and interviewed LD students from the same urban school district who should have been in the graduating class of 1982, and a control sample of non-learning disabled students from the same high schools. Students were part of the LD or non-LD groups based on their status as ninth graders in the 1978-79 school year. Of the $60 \mathrm{LD}$ participants in the study, 28 had completed high school and 32 had left school before graduation, a 53\% dropout rate among LD high school students. In sharp contrast, the dropout rate for non-LD participants was $27 \%$.

A third follow-up study of the 1983 graduating class confirmed the finding again: $39 \%$ of LD students who entered ninth grade in the 1979-80 school year dropped out before graduating from high school, as compared with $22 \%$ of nonhan-dicapped peers (Thornton \& Zigmond, 1988). The picture that was emerging was that students with learning disabilities in this urban area seemed to be leaving high school at nearly twice the rate of nonhandicapped classmates. And follow-up studies in a neighboring blue collar community (Morrow, Thornton, \& Zigmond, 1988) and in rural Virginia (deBettencourt, Zigmond, \& Thornton, 1989) showed that the phenomenon was not limited to the urban school.

Nor were we the only researchers to be reporting alarmingly high dropout rates among students served in special education programs in secondary schools. In Vermont, Hasazi and her colleagues reported that $34 \%$ of mildly handicapped public school youth were not completing a high school education (Hasazi, Gordon, \& Roe, 1985). The reported dropout rate of handicapped youth in several school districts in Florida was pegged at $31 \%$ (Fardig, Algozzine, Schwartz, Hensel, \& Westling, 1985). In a large Alabama county school district, Cobb and Crump (1984) reported a dropout rate of $42 \%$ among students with learning disabilities. In a middle class suburban school district in the Midwest, White, Schumaker, Warner, Alley, and Deshler (1980) found that $26 \%$ of the learning disabled youth had dropped out.

In its Tenth Annual Report to Congress (U.S. Department of Education, 1988), the Office of Special Education Programs (OSEP) reported that in the 1985-86 school year, 26,644 students with learning disabilities, aged 16 through 21 , dropped out of high school before completing their education, an average of 148 students each school day. This figure, which OSEP believed to be an underestimate, represented about $26 \%$ of all students with learning disabilities who left school that year and was nearly double the dropout rate reported by the National Center for Educational Statistics for the general school-aged population (see Rumberger, 1987). Data reported for the subsequent year (U.S. Department of Education, 1989), and data from the National Longitudinal Transition Study being carried out at SRI International under contract from OSEP confirm the finding (see U.S. Department of Education, 1989, p. 70).

My colleagues and I consider the dropout rate to be indirect evidence of the efficacy of secondary school programs for students with learning disabilities, and we find these dropout data compelling and disturbing. Surely if school programs were meeting students' needs, high school students with learning disabilities would not be leaving school! The dropout rates alone force a rethinking of special education services at the secondary school level.

But does it matter that students with learning disabilities are dropping out? Are those who leave school early just as well off in terms of employment and post-school adjustment as their counterparts who stay? Do the dropouts get a "jump on the job market?" Do they get some practical experience out there on the streets that is even better for them than what they get in school? A series of studies on the employment and post- 
school adjustment of graduates and dropouts over the past few years has provided the data to answer these questions: There is a significant differential in employment patterns and postschool adjustment of LD dropouts and LD graduates.

In 1985, we reported that among urban youth, $75 \%$ of LD graduates were employed at the time of follow-up, 18 to 28 months after graduation (see Zigmond \& Thornton, 1985). This contrasted sharply with the employment figures for high school dropouts; only $47 \%$ of LD dropouts were employed. High school leavers who returned to complete their GED were not much better off than those who did not; only $37.5 \%$ of LD youth with GEDs were holding jobs at the time of the follow-up interviews.

In some communities, of course, the job market is extremely good and everyone (graduates and dropouts, handicapped and nonhandicapped) can find a job; such was the case in a rural Virginia Study (see deBettencourt et al., 1989). In other communities the job market is extremely poor and no one can find a job, not graduates or dropouts, handicapped or nonhandicapped; such was the case in the blue collar community studied by Morrow et al. (1988). But in most of our work, and in the work of others across the nation, in terms of the transition from school to work, it pays for students with learning disabilities to stay in high school and graduate. Nevertheless, special education programs for these students seem to have minimal holding power, and many students with learning disabilities drop out of school to face uncertain, grim futures on the streets.

\section{Achievement}

Many researchers have reported academic achievement levels in reading and mathematics among adolescents with learning disabilities that are consistently low, 3 to 5 years behind actual grade placement at entrance to ninth grade (see Cobb \& Crump, 1984; Levin, et al., 1985; Norman \& Zigmond, 1980; Schaloch et al., 1986; Thornton \& Zigmond, 1987a; Warner, Alley, Schumaker, Deshler, \& Clark, 1980; Zigmond \& Thornton, 1985). Unfortunately, students with learning disabilities do not seem to recoup these basic skill deficiencies during their years of attending secondary school resource room programs (Zigmond \& Thornton, 1985; Gregory, Shanahan, \& Walberg, 1986) and, in fact, the gap between achievement scores and grade expectancy level actually seems to widen as students with learning disabilities progress through high school (Norman \& Zigmond, 1980; Warner, Alley, Schumaker, Deshler, \& Clark, 1980).

The follow-up studies we completed speak to this point as well. We have had the opportunity to assess basic skill levels among dropouts, who in general completed only 1 or 2 years of a high school LD program, and graduates, who had at least 4 years. Their achievement levels are essentially the same. Data taken from Zigmond and Thornton (1985), Thornton and Zigmond (1987b) and deBettencourt et al. (1989) illustrate a persistent finding: Special education programs at the high school level fail in their attempts to improve the basic skills of LD adolescents. Many students with learning disabilities enter ninth grade barely literate and leave high school after 1, 2, 3, or 4 years, with literacy skills virtually unchanged.

\section{COMPONENTS OF AN EFFECTIVE HIGH SCHOOL PROGRAM FOR LD STUDENTS}

Over the past decade, several researchers have attempted to delineate factors associated with low achievement and premature school leaving. The results have implicated environmental and family background factors including low socioeconomic level, large family size, established patterns of dropping out in parents and siblings, and non-intact families (Bachman, 1972; Tseng, 1972; Kowalski \& Cangemi, 1974; Lloyd, 1976; Hewitt \& Johnson, 1979; Hill, 1979; Mare, 1980), individual student characteristics including race, gender, IQ, and achievement level (Cervantes, 1965; Çombs \& Cooley, 1968; Kowalski \& Cangemi, 1974; Lloyd, 1976; Kaplan \& Luck, 1977; Hammontree, 1978; Stoughton \& Grady, 1978; Hill, 1979; Howell \& Frese, 1982; Rumberger, 1983), and grade retentions and high absence rates (Schrieber, 1962; Curley, 1971; Dean, 1973; Kowalski \& Cangemi, 1974; Kaplan \& Luck, 1977; Mahood, 1981).

Implicit in much of this research is the assumption that a better understanding of the characteristics of low achievers and dropouts and of their families and communities will lead to the development of school policies and programs that will reduce the number of adolescents who fail to graduate. The intent is noble, but the results have been negligible because the focus on social, family, and personal characteristics does not carry any obvious implications for reshaping school policies and practices.

We share the view of Wehlage and Rutter (1986) that to increase the effectiveness and the holding power of schools, alterable school conditions must be identified. So, in our research and writing over the past decade, instead of focusing on environmental and family background factors or immutable student characteristics, we have concentrated on school program variables - the curriculum and student schedules-and on student behaviors in and around school -behaviors that students can control and that schools can 
teach. These also have been shown to contribute to low achievement and dropping out, and they can be reshaped and redirected.

Four components appear to be essential to more effective secondary school programming for students with learning disabilities: intensive instruction in reading and mathematics; explicit instruction in "survival" skills; successful completion of courses required for high school graduation; and explicit planning for life after high school.

\section{Intensive Instruction in Basic Skills}

Our own research has shown that many high school graduates of secondary school LD programs score at poorer than eighth grade proficiency on a basic skills assessment in reading. Operationally, as the writing sample in Figure 1 illustrates, this means they are barely literate and unable to make functional use of written communications. They also are incapable of meeting the increasingly high demands for literacy that are present in today's reform-minded mainstream high school. As our recent data have shown (see Donahoe \& Zigmond, in press), many students with learning disabilities are now earning failing grades in mainstream courses such as social studies, which place heavy demands on reading and writing, and even in less academically oriented courses such as health.

Some would say that the problem lies within the student; by adolescence, ability to learn basic skills plateaus and further progress in reading proficiency cannot be expected (see Alley \& Deshler, 1979). Nevertheless, our observational studies of instruction in LD resource rooms at the secondary school level would assign the culprit elsewhere.

Figures 2, 3 and 4 summarize data gathered from four 42minute observations in each of eight LD resource rooms in high schools in a large urban school district. Using a time sample protocol (described fully in Zigmond, 1988), observers coded three dimensions of the classroom experience: the activity structure of the class, the behaviors of the LD students being observed, and the nature of the instructional interactions between teacher and students. Activity structure meant how the teacher arranged the class and the assignments. Observers coded activity structures as lecture or largegroup question/answer format, small-group lessons, independent seatwork, or transition (when no activity was assigned to students). Figure 2 shows that students spent more than $85 \%$ of their resource room time assigned to independent seatwork and no time assigned to small group instruction.

Student behaviors were coded into one of three categories: on-task, off-task, or transition (no task to be done). Figure 3

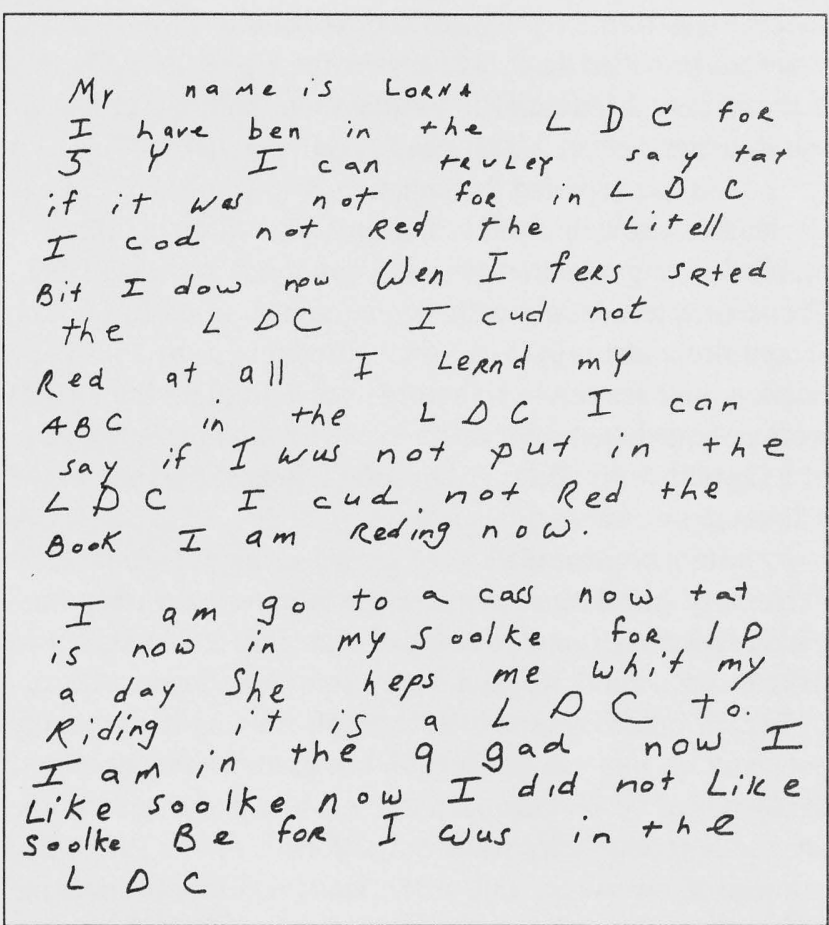

Note: She uses $L D C$ to mean learning disabilities class; $Y$ in the third line means years;

$1 p$ in the second paragraph means 1 period.

\section{FIGURE 1 \\ Composition Written by a Ninth Grade Girl With Learning Disabilities}

shows that students in these LD resource rooms were on-task more than three fourths of the time.

Instructional interactions characterized how the teachers spent their time during each 42-minute period. Teachers could be instructing, listening (to student questions or student answers), managing the flow of academic activities (giving directions for an assignment, telling students to find materials or worksheets or a particular page in a book), socializing with students, or not engaged in any sort of interaction at all with students. Figure 4 shows that LD resource room teachers spent, on the average, slightly less than $40 \%$ of each class period in instructional interactions (instructing and listening), most of these one-to-one interactions with students as they completed worksheets at their desks. Teachers spent about $28 \%$ of class periods telling students what to do but not teaching them how to do it, and another $23 \%$ of class time not interacting with students at all. These data suggest 

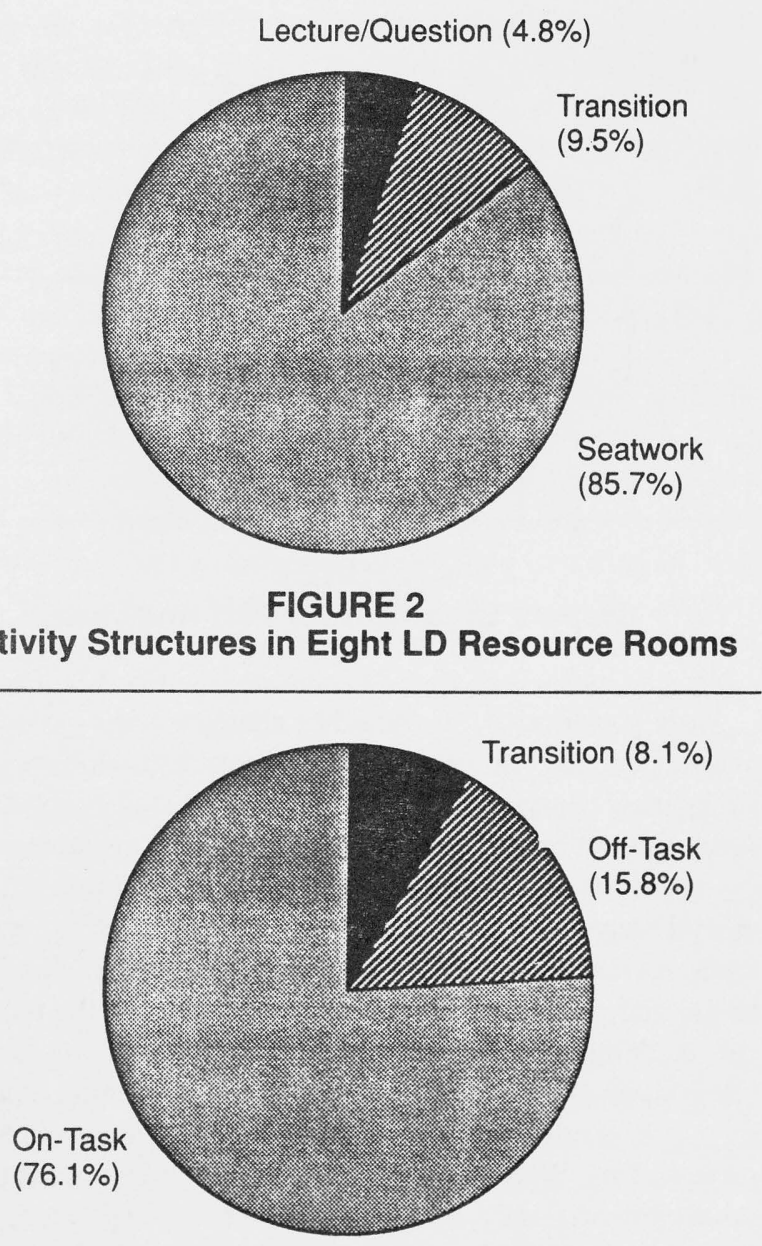

FIGURE 3

Student Behaviors in Eight LD Resource Rooms

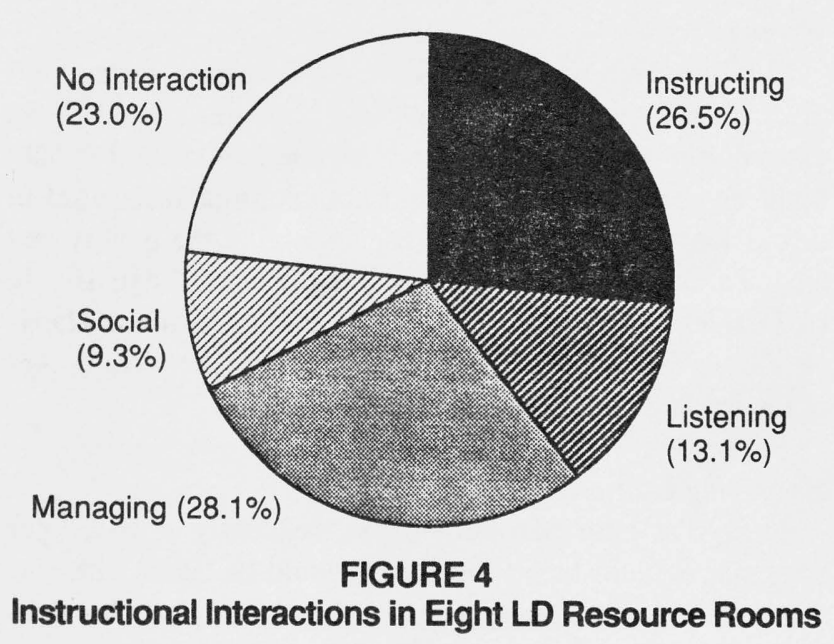

that high school students with learning disabilities may not be making progress in basic skills because they are receiving so little teaching!

\section{Literacy}

We have all heard and read about the crisis of adult illiteracy in the United States. Depending upon the definition of literacy used, the figures on adult illiteracy range from 23 to 78 million Americans (Kozol, 1985), or a minimum of one in five adults who are totally or functionally illiterate. And numbers alone do not adequately portray the complexity of the problem. A disproportionate number of the individuals included in the figures are unemployed, poor, and disadvantaged minorities (Nickerson, 1985).

Students with learning disabilities who leave high school unable to read join this swelling mass of adult illiterates. High school programs for students with learning disabilities must provide intensive, relentless instruction in basic literacy skills to prepare learning disabled students for independence, employment flexibility, and job security.

\section{Reading Instruction}

Instruction in reading at the secondary school level has to be interesting and imaginative. Goals of the reading instruction are to make students independent, fluent readers, confident enough in decoding skills to be willing to attack unfamiliar text in a popular magazine, a novel, a technical manual, or a mainstream textbook. Reading instruction should be individualized but should not be delivered as predominantly one-to-one instruction. Assignments should be based on an analysis of the entering skills of each student, but instruction should be directed to the group, because this arrangement affords all students assigned to the special education teacher during a particular class period more opportunities for teacherdirected instruction and less time on independent seatwork.

Under no circumstances should high school students with learning disabilities simply be placed in a basal reading text series and taught a developmental reading program. Instead, reading lessons should be organized around a three-part curriculum: decoding; vocabulary, comprehension, and fluency; and writing. Time is short, and careful attention must be paid not only to teaching the most critically needed literacy skills but also to building students' self-confidence as readers.

\section{Phonics Review and Decoding}

Each year, students probably will need an intensive phonics review emphasizing word parts and word families, not individual sound-symbol associations (see Bradley \& Bryant, 1985; Fayne \& Bryant, 1981; Williams, 1980; Graham \& Johnson, 1989). Decoding strategies such as those empha- 
sized in the Glass analysis techniques also should be reviewed (Glass, 1978). Rapid drill and practice of words in isolation might be suitable for the early part of the school year, but soon after that, decoding strategies should be practiced in continuous narrative and expository text.

\section{Vocabulary Development}

Although skills are important, the major part of each reading period should be devoted to text-based activities for developing vocabulary, comprehension, and fluency. Text materials should include short stories or novels from a variety of genres (mysteries, real-life adventures, science fiction), selected for high interest and motivation. Most students with learning disabilities have never had the experience of not being able to put down a book, of wanting to read to the end to find out how it all turns out. Few LD students think of themselves as readers competent enough to read for entertainment or distraction. Class time, as well as homework, could be devoted to reading a whole book, although the teacher could read parts of the book aloud, to move the action along. Required repeated readings (see O'Shea, Sindelar, \& O'Shea, 1987) might help students get through particularly difficult or dense sections of the book and also are useful for developing fluency and enhancing comprehension.

During text reading, opportunities should be afforded to review decoding strategies for words in context and to develop vocabulary through semantic mapping and group discussion (see Calfee, 1976; McKeown \& Beck, 1988). Teachers also should teach students strategies for understanding the structure of narrative text and engage students in plot and character analyses using graphic organizers such as those depicted in Figures 5 and 6 . But mostly, with narrative texts, students should be encouraged to read for the pleasure of reading.

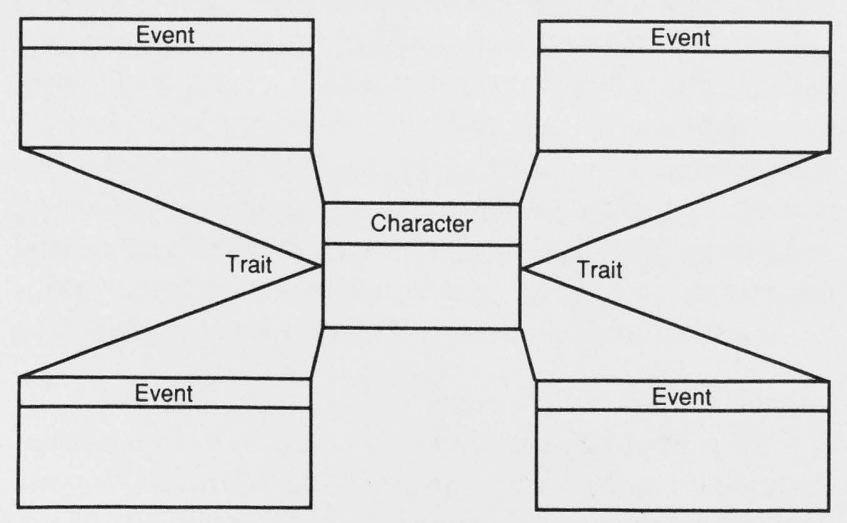

FIGURE 5 Graphic Organizer for Character Analysis
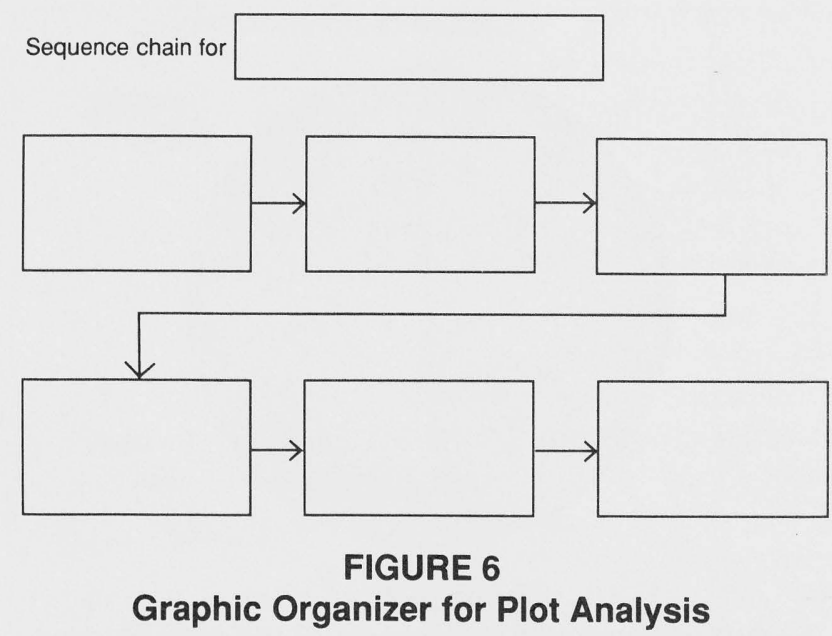

Work on narrative text should be alternated (in 4- to 6-week cycles, perhaps) with work on expository text. Now, popular magazines, newspapers, or science, social studies, or health textbooks can be used as vehicles for developing strategies to cope with exposition. Strategies involving summarization, mental imagery, self-questioning, question answering, and so forth, reviewed by Graham and Johnson (1989), should be taught and practiced. Of particular use might be the reciprocal teaching strategy introduced by Palinscar and Brown (1984), which involves summarization, questioning, clarifying, and predicting, or the self-monitoring strategies reviewed by Wong (1986). Opportunities for vocabulary development should not be overlooked in expository text reading, again using semantic mapping and graphic organizers to help students see relationships among word meanings and concepts.

\section{Writing}

Finally, some part of each week of reading instruction must be devoted to writing. Writing activities should be an extension of the reading comprehension lessons and should build on the semantic maps and graphic organizers used in discussions of text. Strategies for improving the quality and technical adequacy of student writing, discussed extensively by Deshler (Alley \& Deshler, 1979) and Graham and Harris (1989a, 1989b), should be incorporated into the writing part of the reading curriculum as well.

\section{Measuring Learning}

At regular intervals, perhaps as frequently as twice per week, curriculum-based measures should be taken with students who are reading well below the eighth grade level, to 
determine whether they are profiting from instruction. Students may be asked to complete 1-minute oral readings from grade-appropriate text material (see Deno \& Mirkin, 1977) or to complete maze tasks delivered via computer (see Fuchs, Hamlett, Fuchs, Stecker, \& Ferguson, 1988). Performance data then should be graphed and analyzed for trend. These CBM data provide a global indicator of reading fluency, a measure that is sensitive to improvements in reading performance over time.

If CBM data show a student making steady improvements (see Figure 7), the teacher can feel confident that the reading program is working. If a student's CBM data indicate a level or downward trend (see Figure 8 ), the teacher is informed that a change in the instructional program is warranted, that "business as usual" is no longer appropriate for this student. The change may involve tutoring the student in a strategy the rest of the class has mastered, changing the intensity and frequency of teacher feedback to the student during reading instruction, changing the nature of the assignments during independent seatwork, changing the incentives for student performance (see Howell \& Morehead, 1987). Whatever the change, continual monitoring of CBM data will inform the teacher of the success of the new approach or of the need to continue to adjust instruction.

\section{Math Skills}

Intensive instruction in basic skills is not, of course, limited to reading and writing domains. Math skills of high school LD students also demand considerable attention.

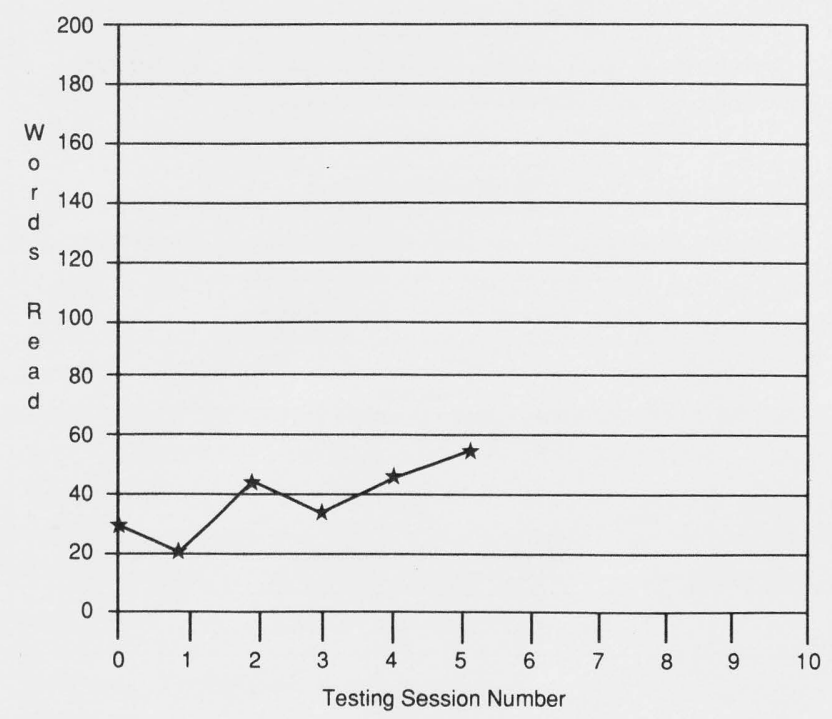

FIGURE 7

J.B.'s CBM Scores

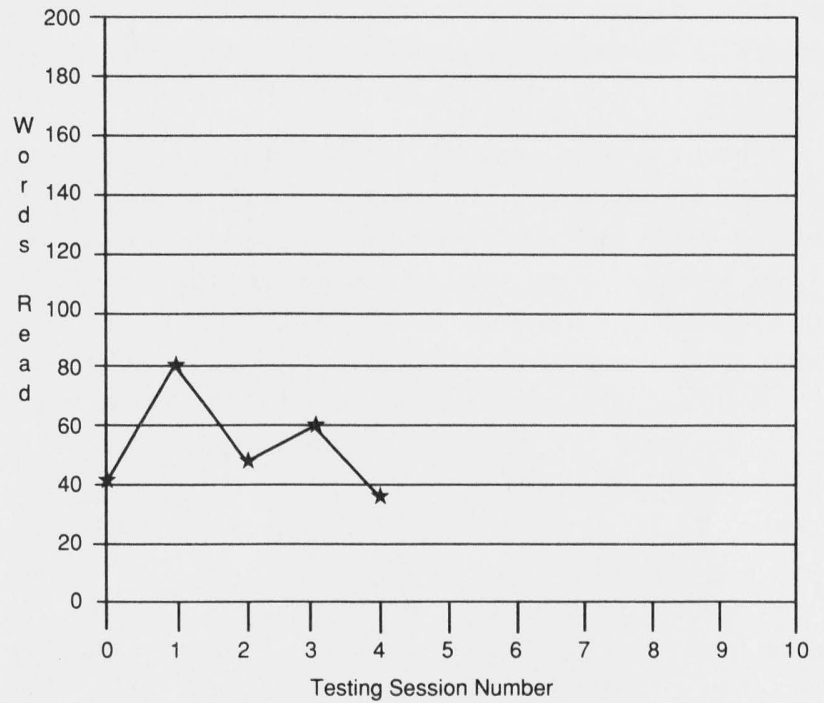

FIGURE 8 C.A.'s CBM Scores

Many students have not acquired fluency in basic math facts by the time they enter ninth grade. More important, they don't understand or feel comfortable using mathematics in everyday life-in shopping, measuring, estimating prices, solving problems.

A functional math curriculum should teach students basic algorithms up through simple algebra but emphasize problem solving and practical applications of math concepts. Lloyd and Keller (1989) provide excellent suggestions for effective math instruction for LD students, which could be used at the secondary school level. Problem-solving strategies being explored by Cawley and his colleagues (see Cawley, Fitzmaurice, Shaw, Kahn, \& Bates, 1978, 1979a, 1979b; Cawley, Fitzmaurice-Hayes, \& Shaw, 1988) also are particularly relevant in teaching mathematics to LD students in secondary school.

\section{Explicit Instruction in Survival Skills}

Several years ago we introduced readers of Focus on Exceptional Children to a curriculum for teaching coping skills to adolescents with learning disabilities (Silverman, Zigmond, \& Sansone, 1981). We have not changed our minds about the importance of these survival skills to the successful functioning of high school students with learning disabilities, or about the need to teach these skills explicitly. A survival skills curriculum would have three strands: behavior control, teacher-pleasing behaviors, and study skills/test-taking strategies. Descriptions of the objectives of each of these 
strands and sample activities were provided in Silverman et al. (1981). Some extensions of these ideas are provided next.

\section{Behavior Control Activities}

Behavior control activities are designed to help students who are always getting into trouble, who consistently do the wrong things, and who often are suspended or punished. These students do not seem to understand the role they play in creating the conflicts in which they are continually involved. In behavior control activities the goal is to help students alter their locus of control from external ("I'm not at fault; someone else made these things happen to me") to internal ("I behaved in a certain way so these things happened; if I behave differently, different things might happen"). Students learn to take responsibility for their actions. They learn alternative ways of responding to situations that arise in the everyday course of school. They learn that they can change their school lives because they can change their own behaviors.

As is the case in all three strands of the school survival skills curriculum, teaching behavior control relies heavily upon simulations and role playing to help students learn to recognize what they and others do in school situations, the impact of one's behavior on other people, alternative ways of responding to specific situations, and the consequences of behaving one way or another. Early experiences in teaching behavior control in secondary schools have taught us that students with learning disabilities cannot use simulations or role playing effectively without explicit instruction in how to observe and document. So we spend time, initially, teaching students to use a graphic to organize their observations and record their feelings and impressions. An example of one such graphic is presented in Figure 9.

Once students are good observers, efforts can be concentrated on the content rather than on the process of the simulation or role play. Now we introduce a problem-solving strategy to help students become analytic about their experiences in school and their personal responsibility for events and consequences. The graphic displayed in Figure 10 becomes the basis for a group discussion on alternative ways of responding to situations such as the following:

As you are walking down the hall with a few of your friends, you see someone you know way down at the other end of the building. You call to him. Right at that moment, a teacher steps out of her classroom. She is very upset that you have disturbed her class while they are taking an important test.

You are standing in line at the cafeteria. As you are waiting, two students attempt to cut in front of you. You have been waiting patiently for some time, and you think this is unfair.

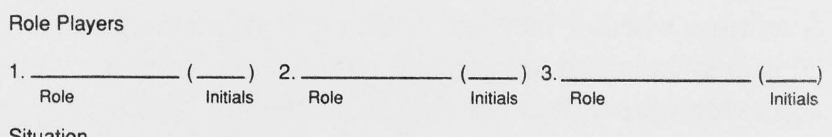

Situation

Directions: Place an "X" on each line below to describe the role players' behaviors. Focus on the role or behaviors rather than on the individual playing it.
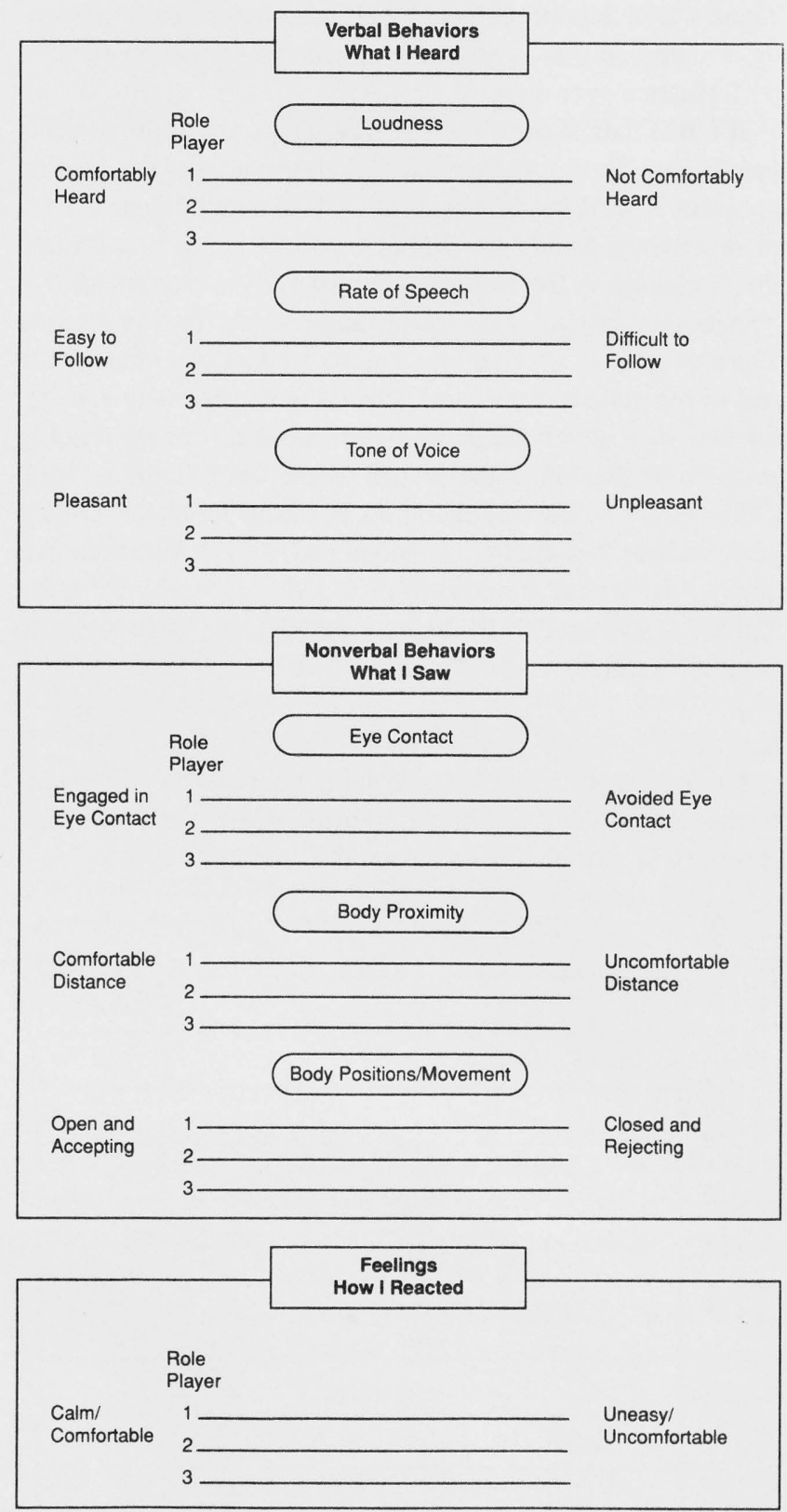

FIGURE 9

Graphic to Teach Students to Observe and Analyze Role Playing 


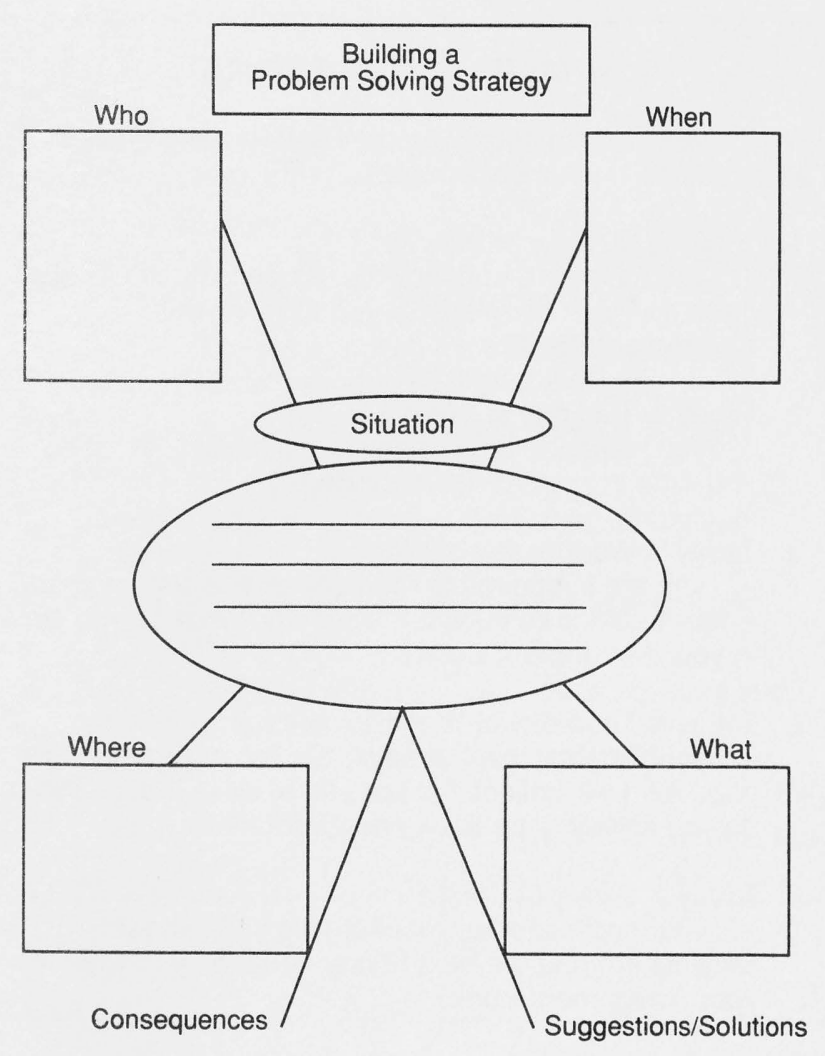

FIGURE 10 Graphic for Development of Problem-Solving Skills

Students analyze the situation, discuss alternative ways of behaving, act out the various ways, and analyze the probable consequences of each scenario. Some role playing is videotaped so that the action can be replayed, observed, and stopped for extended discussion. Then, after practicing alternative behaviors within the safe environment of the resource room, students are encouraged to try new behaviors in their interactions around the school. They also are encouraged to keep track of the extent to which using behavior control strategies changes the rate at which they are assigned suspensions, detentions, demerits and so forth.

\section{Teacher-Pleasing Behaviors}

Teacher-pleasing behaviors focus on the behaviors students use to cope with rules and demands within their classes.
This part of the curriculum helps students acquire behavior patterns that usually lead teachers to consider students more positively. Most students learn, in an incidental fashion, that certain behaviors ingratiate students with the teacher. These students learn to make eye contact, look interested in the lesson, volunteer responses in class, look busy. Many students with learning disabilities do not learn these behavior patterns, and their failure to display teacher-pleasing behaviors puts off the teacher.

The LD student often needs to be taught, explicitly, how to act like a "good" student. Since writing the Focus on Exceptional Children article in 1982, my colleagues and I have developed scripts for 20 lessons on teacher-pleasing behaviors (see Zigmond, Kerr, Schaeffer, Farra, \& Brown, 1986). During one of the earliest lessons, students complete a School Survival Skills Scale, a self-assessment of schoolappropriate behaviors. Then each student compares the selfgenerated profile with one derived from a Scale completed by one of his or her mainstream teachers. The exercise helps students become aware of their own behaviors and of differences in how they view themselves in regular classes and how mainstream teachers view them in these same classes. The remaining lessons cover four basic aspects of behavior, as follows:

Attendance

- Coming to school

- Coming to class

- Coming on time

- Coming prepared

Assignment Completion

- Keeping track of assignments

- Turning in classwork/homework

Attentiveness

- Being more "on-task"

- Responding to teacher requests

- Asking questions/making comments

Compliance behavior

- Reducing disruptive behavior

- Talking more "appropriately"

Instructional formats and activities vary considerably from lesson to lesson to maintain student interest and active participation. For example, we use a pencil-and-paper task for an acitivity on remembering (see Figure 11). This remembering activity comes just before a simulation task on how to use an assignment book (Figure 12). In contrast, we use a Q-sortlike task to get students to think about appropriate classroom 
Name

Date

Directions: Put a check in the appropriate box.

\section{Have you ever forgotten:}

1. to bring in a field trip permission slip?

2. to study for a test?

3. to bring in your homework?

4. to find a newspaper or magazine article?

5. to attend chorus or football practice?

6. to hand in a book report?

7. to bring in something you did for extra credit?

8. to bring your just-washed gym clothes from home?

9. to bring lunch or lunch money?

10. to bring in an excuse for being absent?

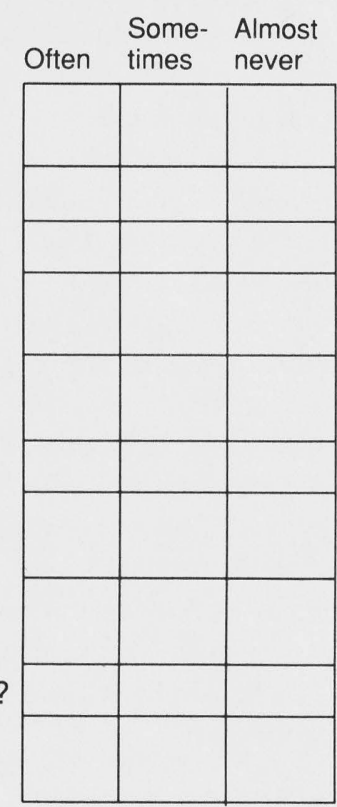

\section{FIGURE 11}

\section{School Survival Skills Curriculum: Task on Remembering}

behavior. The statements in Figure 13 are each printed on a $4 \times 6$ card, and each student receives an entire deck of 16 cards. Students silently read the statements on the cards and sort the cards into two piles representing "cool" and "not cool" classroom behaviors. Then the students engage in a group discussion of the cards in each pile.

An important aid in teaching students to use new teacherpleasing behaviors involves self-monitoring strategies. Students contract to perform first one, then more and more of the target behaviors. Students daily record whether they performed these behaviors, on self-monitoring forms checked by the special education teacher at regular intervals. The number of skills that students self-monitor increases gradually until students are recording their performance on as many as seven or eight skills. Figure 14 is a sample of a self-monitoring form used in the School Survival Skills Curriculum (Zigmond et al., 1986), on which students are recording behaviors of coming to class; arriving on time; bringing note-

\section{"WHAT IF . . ? ?" WORKSHEET}

What if you are monitoring yourself and keeping track of assignments in your English class, and ...

1. Today is Monday of Week 1 ... you have an essay to write, which is due in English class on Tuesday. What do you write in your Assignment Book?

2. Today is Tuesday of Week 1 ... you have a test on Friday in math class. What do you write in your Assignment Book?

3. Today is Wednesday of Week 1

. . . you are supposed to read pages 192-241 in your English Literature book for Thursday. What do you write in your Assignment Book?

4. Today is Thursday of Week 1

... your English teacher says, "Do the assignment on page 42 . I will collect it at the end of class today." What do you write in your Assignment Book?

5. Today is Friday of Week1

... your social studies teacher tells you that term projects are due the next Friday. What do you write in your Assignment Book?

TURN TO NEXT PAGE

WE ARE STARTING A NEW WEEK NOW.

6. Today is Monday of Week 2

... you have to write another essay for English class on Wednesday. What do you write in your Assignment Book?

7. Today is Tuesday of Week 2

... your English assignment (an essay), which was due on Wednesday, has been postponed until Thursday. What do you write in your Assignment Book?

8. Today is Wednesday of Week 2

. . . your science teacher tells you that Friday you have to make up the unit test that you missed when you were absent last week. What do you write in your Assignment Book?

9. Today is Thursday of Week 2

. . . you didn't have an English assignment on Wednesday because there was an assembly and you did not have English class. What did you write in your Assignment Book? 
Card

Number

1. Even if I'm daydreaming, I keep my eyes open and look at the teacher.

2. When the teacher asks a question, I raise my hand even if I'm not sure of the answer. If she calls on me, I'll ask her, politely, to repeat the question.

3. It is O.K. for me to correct the teacher during the lecture if he or she makes a mistake.

4. It is O.K. to sharpen my pencil while the teacher is talking.

5. During a class discussion I take the opportunity to comb my hair.

6. During English class I am doing my homework for math class.

7. When I need help with my work, I raise my hand and wait for the teacher to come.
Card

Number

8. I don't bring my text to class so that I don't have to do the work assigned.

9. Sometimes I use the dictionary during class time.

10. It is O.K. to talk to my friends during class if I whisper.

11. I don't understand the assignment sheet, so I ask for help.

12. If someone gets in trouble during class, I stop what I am doing to see what's going on.

13. I copy from the chalkboard only the words that make sense to me.

14. If I think I can't do an assignment, I just put it down.

15. I never participate in class discussions.

16. Classtime is a good chance for me to read a magazine or the paper.$$
\text { Name }
$$

Directions:

Put a check $(\boldsymbol{})$ if you did each step.

Put an " $X$ " if you did not.

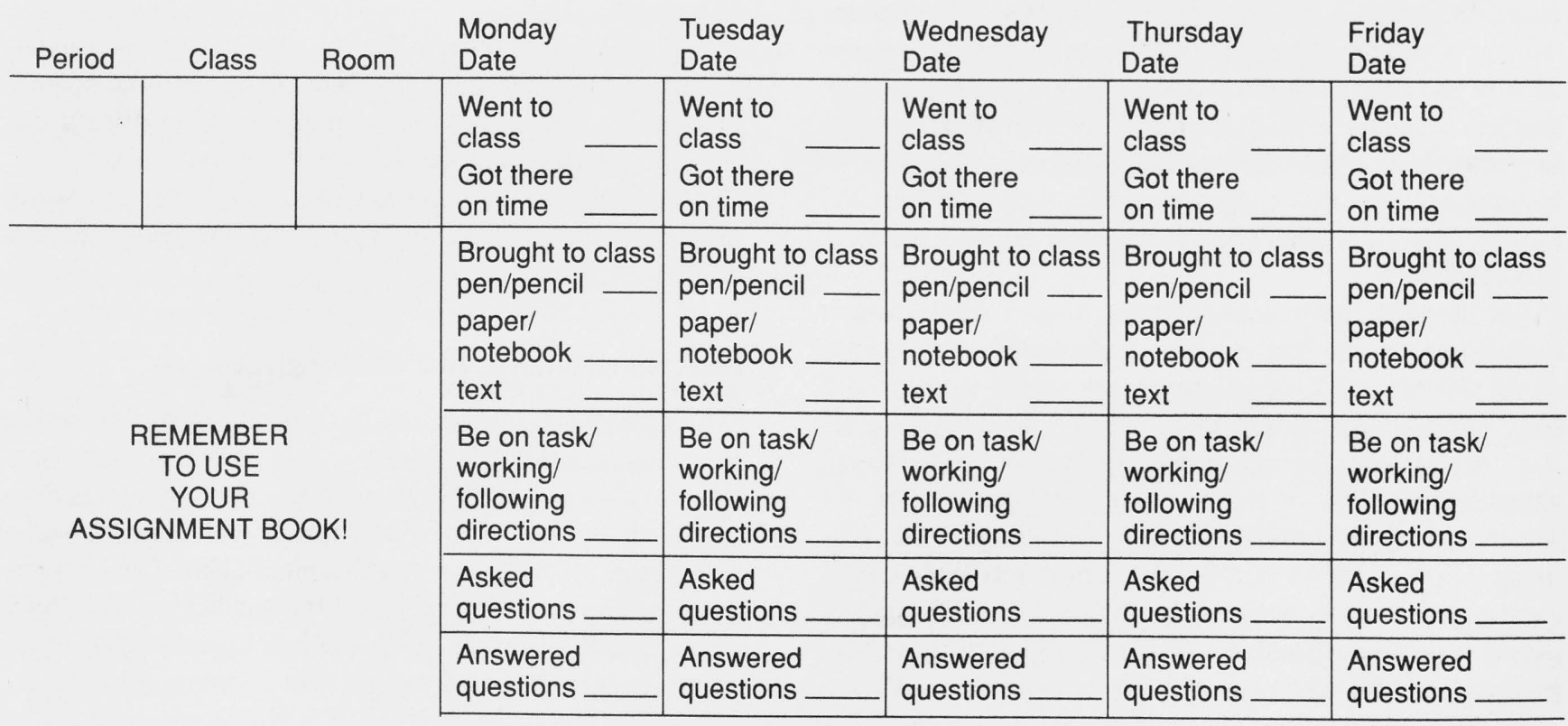


book, paper, and text; staying on task; following directions; asking questions; answering questions; and entering assignments in an assignment book for one mainstream class for one week of school. Figure 14 shows this self-monitoring form.

Study Skills and Test-Taking Strategies help LD students organize their time, approach a textbook, take notes from a lecture or a text, organize information, study for tests, and take tests. The goals of the study skills component of the school survival skills curriculum is to teach students strategies for gathering and retaining information that they will use in completing assignments and fulfilling the requirements of content subject courses. Students are taught systematic methods for approaching classroom tasks and for compensating for deficiencies in basic skills. The activities of this component draw heavily on the work of Deshler and his colleagues (see Alley \& Deshler, 1979) as well as on timehonored study skills such as SQ3R (see Alexander, 1985; Schumaker, Deshler, Alley, Warner, \& Denton, 1982).

\section{Successful Completion of Courses Required for Graduation}

When students with learning disabilities are assigned to resource room programs, they take most of the courses they need in order to graduate from high school in the mainstream. Our research shows that LD students in these courses cut class frequently and are often late to the classes they do attend (Zigmond, Kerr, Brown, \& Harris, 1984). They arrive without a writing implement, notepaper or textbook at least $30 \%$ of the time (Zigmond et al., 1984). Their mainstream teachers characterize them as being poor at organizing themselves and their time, taking notes, identifying main ideas in lectures or texts, following directions, and completing and turning in assignments (Barrett, 1986; Zigmond, Kerr, \& Schaeffer, 1988).

Despite these deficiencies, some students with learning disabilities do not fare too badly. Zigmond et al. (1985) found that only $20 \%$ of LD secondary school students in a large urban school district failed more mainstream courses than they passed. Overall passing grades were obtained in approximately $75 \%$ of courses, and more than $30 \%$ of the students passed everything they took. But Donahoe and Zigmond (in press) found that, 5 years later in this same school district, although approximately $75 \%$ of LD ninth graders passed mainstream health courses, only $60 \%$ passed science, and less than $50 \%$ earned passing grades in social studies.

Students with learning disabilities who are successful in high school participate actively and efficiently in the educational process. They can describe the skills that are important for making it in high school, and their behavior is consistent with their rhetoric (Brown, Kerr, Zigmond, \& Harris, 1984). In contrast, the unsuccessful high school students seem to function in a more passive, less efficient manner, and their behavior is not consistent with their apparent knowledge of school rules and expectations (Kerr, Zigmond, Schaeffer, \& Brown, 1986; Zigmond et al., 1988; Zigmond et al., 1984). Consistently, across studies and research teams, students with learning disabilities who fail mainstream courses can be differentiated from those who pass on the basis of class attendance behaviors (failing students have significantly higher absence rates) and proficiency in learning strategies and organizational skills (Alley \& Deshler, 1979; Barrett, 1986; Donahoe \& Zigmond, in press; Warner, et al., 1980; Zigmond et al., 1988).

In designing a secondary school program for LD students, something must be done about these failure rates because the consequences of failing courses needed for graduation are serious. Our data (Thornton \& Zigmond, 1986) show that students who fail to accumulate sufficient numbers of required credits to pass ninth grade inevitably drop out of high school before graduation. Passing ninth grade does not guarantee successfully completing high school, but failing ninth grade is devastating to students with learning disabilities.

Three approaches can be taken to this problem:

1. School survival skills and strategies training may make the student more capable of coping with the demands of the mainstream.

2. A consulting teacher may be able to influence mainstream teachers to alter the demands of the mainstream environment to accommodate students' learning difficulties (Miller, Leinhardt, \& Zigmond, 1988).

3. Students could be placed in less demanding courses to meet graduation requirements (Hartwell, Wiseman, \& Van Reusen, 1979).

\section{Explicit Planning for Life After High School}

More and more educators have begun to recognize the need to provide $\mathrm{LD}$ adolescents with opportunities to prepare them for a successful transition to life after high school. Several studies, our own included, indicate that a small proportion of students with learning disabilities $(12 \%-30 \%)$ continue on to 2- and 4-year colleges after graduating from high school (see White et al., 1980; Cobb \& Crump, 1984; Association for Children and Adults with Learning Disabilities, 1982; Zigmond \& Thornton, 1985; Hoffman et al., 1987). These students need help in selecting appropriate higher education institutions, in arranging for adapted versions of col- 
lege entrance examinations, and in completing the applications for admission.

The non college-bound students need help in planning what they will do with their lives, what occupations might be satisfying, and what training might be needed both in high school and after it. As part of transition planning, many students with learning disabilities are being counseled into a vocational education high school track, but placement in vocational education does not guarantee a successful transition. In fact, Zigmond and Thornton (1985) found no basis for assuming that mainstream vocational education programs better prepared LD students for the world of work than the more traditional academic curriculum. In their first follow-up sample, the post-high school employment picture was no better for the 10 students with learning disabilities who were vocational education graduates than for the $16 \mathrm{LD}$ students who were graduates of a regular high school curriculum.

Thornton (1987) further explored the relationship between completing an intensive mainstream skill-centered vocational training program in high school and post-school employment patterns. She interviewed a sample of young adults with learning disabilities who had graduated from high school nearly 2 years prior to follow-up. Thornton hypothesized that the skills acquired in vocational training experiences would give $\mathrm{LD}$ vocational education graduates an advantage in the post-school employment market over LD graduates who had not taken vocational education courses. Again, the hypothesis was not confirmed. The two groups showed no differences on several measures of post-school adjustment, including employment rates (approximately $61 \%$ in both groups) and percentage of time employed since graduating from high school (approximately 50\% for both groups). Furthermore, only $35 \%$ of the vocational education graduates were in postschool employment or training that even remotely related to their high school vocational education curriculum.

A second measure of the benefits of vocational education for LD students relates to the assumption among vocational educators that enrollment in vocational training classes in high school tends to hold in school students who otherwise might drop out (Weber \& Silvani-Lacey, 1983). Thornton and Zigmond (1987b) examined the holding power of mainstream vocational education for $\mathrm{LD}$ adolescents by analyzing the risk status of those enrolled in vocational programs in a large urban school district. We assigned a dropout risk status to all students on the basis of their ninth grade attendance and course completion. We found that the holding power of vocational education for LD students at greatest risk for dropping out was minimal, at best, because the majority of high-risk LD students left school before entering their third year of high school, (i.e., before they could access their first skill-centered mainstream vocational training courses).

LD students who persisted in school long enough to enroll in the vocational education track were actually low-risk in terms of school dropout (based on ninth grade attendance and course completion data) and were expected to finish high school regardless of their course choices. Furthermore, the few high-risk LD students who persisted in school long enough to access vocational training courses still left school before graduation.

Many LD students want to learn practical skills during their years in high school. Figure 15 is an indication of one student's desire to do this. Nevertheless, school personnel charged with developing appropriate transition planning opportunities for LD students must recognize that enrollment in vocational education programs in the junior and senior years may not be the only answer.

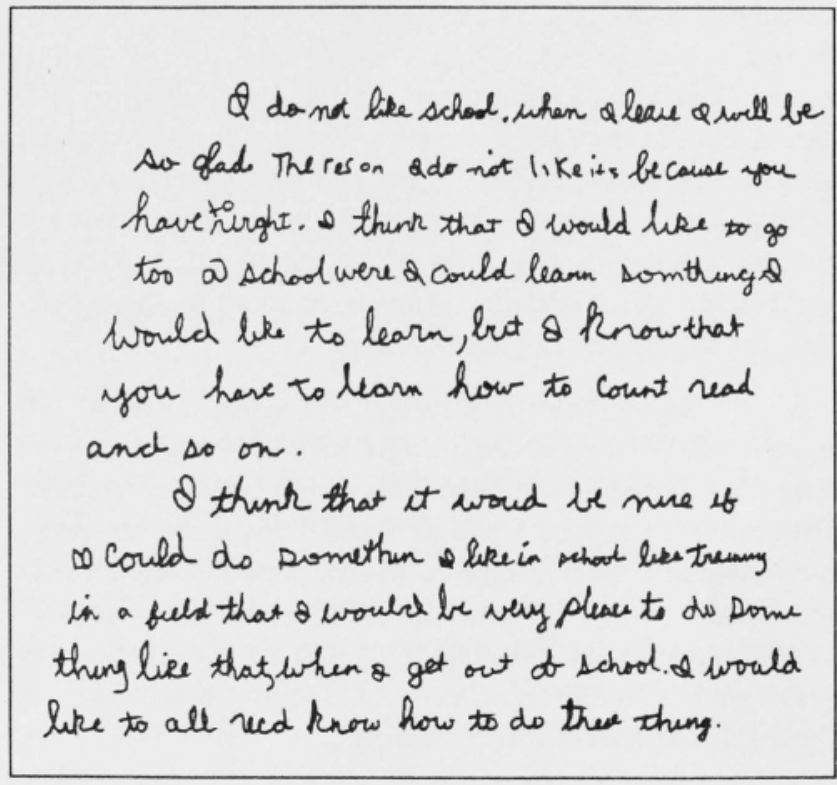

\section{FIGURE 15}

\section{Composition Written by a Ninth Grade Boy with Learning Disabilities}

\section{TWO MODELS OF SERVICE DELIVERY}

A comprehensive high school program for students with learning disabilities must contain the four components just discussed: intensive instruction in basic skills, explicit instruction in survival skills, successful completion of courses required for graduation from high school, and explicit planning for post high school life. The challenge for schools is to 
construct an efficient and affordable service delivery model with the appropriate combination of special and mainstream educational experiences to address these components, and at the same time to develop an appealing and motivating educational program that holds students in school.

The best model will accomplish little if students abandon it early in their high school careers. I propose two ways in which the four components can be organized into a comprehensive high school program for students with learning disabilities. The models differ in the extent to which they rely on direct services from special education personnel and in their emphasis on preparation for work as contrasted with post secondary education or training.

\section{Model One: Less but Very Special Special Education}

The first model for special education services at the secondary school level could be subtitled "Back to the Future" because it looks much like the model of services first proposed in our 1975 CSDC (see Zigmond, 1978). In this model, special education personnel are responsible for educating LD students for three periods per day in ninth grade and two periods per day in the remaining years of high school. The mainstream high school program is offered to the students for the remainder of the school day. Model One utilizes the special education resource room as the service delivery setting and has five features:

1. LD Students are assigned to mainstream classes for math, content subjects required for graduation, and elective courses. LD students are scheduled to take basic math courses with nonhandicapped students who likewise are not proficient in math. Basic, applied math courses offered in the mainstream are used to meet the math requirements for graduation. Students also are scheduled into mainstream science, social studies, and health classes so as to profit from learning these subjects from a content specialist.

2. One special education teacher is assigned as a support or consulting teacher to work with mainstream teachers in whose classes LD students are placed. Many LD students do not have the skills to manage the setting demands of the mainstream. In contrast to the individualized instruction in secondary school resource rooms, the majority of student time in mainstream academic classes is spent in teacherdirected, large-group instruction (Zigmond et al., 1984) with the instructional configuration most likely to be individualistic and competitive (Johnson \& Johnson, 1978). Regular class teachers spend a great deal of time lecturing and at a speed that often makes note taking difficult (Moran, 1980).
Mainstream content subject teachers offer few opportunities for student involvement in discussion and rarely present advanced organizers to help students listen more effectively or check on student apprehension of the content delivered by asking students to paraphrase what they have heard. Mainstream teachers typically evaluate competence through written products and infrequently provide direct oral feedback and reinforcement (Moran, 1980). Few regular class teachers spend time teaching test-taking skills (Cuthbertson, 1978). Teachers assume that students are capable of gaining knowledge of the material to be tested from reading textbooks or from absorbing information presented in lectures and class discussions. Few teachers offer students in a mainstream class the opportunity to retake a test on which they have performed poorly.

A special education teacher in the role of support or consulting teacher will work with mainstream faculty to change their attitudes, expectations, and teaching and testing styles. The support or consulting teacher role has been shown repeatedly to facilitate successful integration of LD students into mainstream academic courses (see Graden, Casey, \& Bonstrom, 1985; Polsgrove \& McNeil, 1989; West \& Idol, 1987; Laurie, Buchwach, Silverman, \& Zigmond, 1978), although to be effective, the role of consulting or support teacher in a high school must be considered a full-time indirect service special education job, not an activity tacked onto the job of a direct service resource room teacher.

3. Additional special education teachers are responsible for yearly English/reading courses, one survival skills class, and a supervised study hall, which LD students are scheduled to take each year of high school. The curriculum of the English/reading courses over the four years of high school would follow the pattern outlined earlier in this article. It would include attention to decoding, vocabulary, comprehension and fluency, and writing. It would emphasize text-based instruction, make heavy use of graphic organizers in developing vocabulary and concepts, teach strategies for coping with narrative and expository text, and use curriculum-based measurement in reading to monitor student progress and signal needed changes in the instructional program.

The survival skills course would be offered to all ninth grade students with learning disabilities, and to any student assigned to the LD program after ninth grade or transferring into the high school after ninth grade. Attention would be paid to teaching behavior control, teacher-pleasing behaviors, and study skills.

Each year, students would be scheduled for a study hall supervised by an LD teacher. This study hall would provide 
an opportunity for the students to receive guidance on homework assignments, to be coached to use reading comprehension strategies, learning strategies, and study skills that they have been taught in the English/reading and survival skills courses, and to receive tutoring, if necessary.

4. From the start of ninth grade, $L D$ students interact regularly with a counselor for transition planning. A counselor who is knowledgeable about the needs of students with handicaps is assigned to counsel LD students on transition planning beginning early in ninth grade. Outcomes of these discussions are reflected in the selection of elective courses over the 4-year period so that students develop a growing sense of direction and purpose. The counselor helps students who are college-bound in the application process as early as the end of the sophomore year, when it may be appropriate to begin taking college entrance examinations.

5. Courses required for graduation are spaced evenly throughout the four years to reduce academic pressures, particularly in ninth grade. Students never take a full load of courses, because each year includes a study hall. In addition,

\begin{tabular}{|c|c|c|c|}
\hline Year 1 & Year 2 & Year 3 & Year 4 \\
\hline $\begin{array}{l}\text { English/ } \\
\text { Reading* }\end{array}$ & $\begin{array}{l}\text { English/ } \\
\text { Reading* }\end{array}$ & $\begin{array}{l}\text { English/ } \\
\text { Reading* }\end{array}$ & $\begin{array}{l}\text { English/ } \\
\text { Reading* }\end{array}$ \\
\hline Math & Math & Math & \\
\hline \multirow[t]{2}{*}{$\begin{array}{l}\text { Social } \\
\text { Studies }\end{array}$} & & $\begin{array}{l}\text { Social } \\
\text { Studies }\end{array}$ & $\begin{array}{l}\text { Social } \\
\text { Studies }\end{array}$ \\
\hline & Science & Science & Science \\
\hline $\begin{array}{l}\text { Survival } \\
\text { Skills }^{\star}\end{array}$ & & & \\
\hline Study Hall* & Study Hall* & Study Hall* & Study Hall* \\
\hline PE/Health & $P E$ & PE/Health & $P E$ \\
\hline \multirow[t]{2}{*}{ Elective ${ }^{* *}$} & Elective $^{\star \star}$ & Elective $^{\star \star}$ & Elective $^{\star \star}$ \\
\hline & Elective $^{\star \star}$ & & Elective $^{\star \star}$ \\
\hline
\end{tabular}

* Course taught by special education teacher.

** Electives selected with advice from counselor to meet distribution requirements for graduation, college entrance requirements for students considering post-secondary education, and/or student's vocational interests.

Note: This schedule meets Pennsylvania requirements for graduation. one required course traditionally scheduled for ninth grade is slipped to eleventh grade to increase the likelihood that students will pass required courses in ninth grade and beyond and persist in school.

Figure 16 provides a 4-year schedule of courses for students in Model One. The schedule is designed to meet graduation requirements in the Commonwealth of Pennsylvania and assumes that, for their elective courses, students will be guided to take the two courses in arts or humanities that round out the requirements. The schedule also assumes that students carry seven classes at a time and are scheduled for each of them 5 days per week. The program of study outline in Figure 16 contains all four of the essential components of an effective LD program: intensive instruction in basic literacy skills (delivered by a special education teacher) and functional math skills (delivered in the mainstream); explicit instruction in survival skills (available as a course to be taken in ninth grade); opportunities for success in courses required for graduation (through the availability of a full-time consulting teacher, a shift in the scheduling of required courses, and a reduced schedule that incorporates a study hall supervised by a special education teacher); and explicit planning for post-school life (through counseling and judicious scheduling of six elective courses).

Model One is, however, appropriate only for certain students with learning disabilities. Students who are collegebound should be exposed to subject matter taught by mainstream content subject specialists, and they have to test themselves in a context larger than special education. Model One provides these college-bound students with that opportunity. In addition, students who are uncertain about their plans beyond high school and who do not want to limit their postsecondary education or training options would be well served in Model One, if they have sufficiently developed language and social skills to cope with mainstream content demands.

One advantage of Model One is that most special education teachers currently in the field feel comfortable teaching English/reading, although most of these teachers will need considerable inservice training to help them change the direction and emphasis of the curriculum. They also will need training in how to teach survival skills. Furthermore, in implementing this model, special education teachers will have to be enjoined against drifting into tutoring in content subjects during English/reading and survival skills instruction.

In implementing Model One, administrators will face at least two challenges. One will be to develop a school climate that promotes accommodation to students with learning dif- 
ferences in the mainstream. Principals play a key role in setting the tone of a school building, and their support will be critical to accomplishing changes in mainstream attitudes and instructional styles needed if students with learning disabilities are to be accommodated successfully. The second challenge facing administrators will be to support the role of a full-time consulting teacher, troubleshooting with teachers and students across the school. Teachers who do not have direct service responsibilities are uncommon in secondary schools, yet this role will be critical to successfully implementing Model One.

Model One, the resource room model, is consistent with the mandate of PL 94-142 for education of students with handicaps in the least restrictive environment. It combines opportunities for special instruction with opportunities to accumulate mainstream academic credits to meet high school graduation and college entrance requirements. But the Model One service delivery alternative is not for everyone.

\section{Model Two: More Special Education}

Restructuring, the rising tide of the school reform movement, is part of the response of the education community to criticisms originating in the A Nation At Risk report (National Commission on Excellence in Education, 1983). The basic agenda of the restructuring movement has been to increase the academic pressure of the schools, to increase achievement in core skills, to increase student competence in higherorder thinking skills, to produce a high school graduate who is better prepared to enter the workforce so that America can compete successfully with Europe and the Pacific Rim countries. Restructuring at the high school level has meant tougher, more uniform standards; increased graduation requirements in mathematics, science, foreign languages, and technology; harsher grading; less leniency.

The restructuring of mainstream education has come at a time of intense pressure to restructure special education, as well. Many researchers, practitioners, and policy makers in the special education community have been calling for a restructuring of services for "hard-to-teach" students and have proposed that regular education classrooms can be made to work effectively for all students. That pressure to return handicapped students to mainstream instruction is known as the regular education initiative (Will, 1986). Advocates of the regular education initiative (REI) assume that schools are prepared to accept a wider range of abilities and to deliver a diversity of educational options within the regular classroom.

The reality is quite different, especially at the high school level, because the restructuring effort in special education is simply not compatible with the restructuring effort in regular education. The mainstream reform effort sets rigid standards for acceptable school behavior; special education reform asks mainstream teachers to expand their tolerance of individual behavioral differences. The mainstream reform effort increases the rigor of the curriculum; the special education reform asks teachers to be more flexible, more thoughtful, more selective in curriculum coverage. The mainstream reform effort introduces uniform testing programs and grading guidelines; the special education reform asks teachers to adapt testing procedures and grading standards to accommodate students with special needs.

Recognizing the impact of mainstream reform efforts on high school teachers and high school programs, Model Two calls for increasing the level of responsibility of special education personnel for educating students with learning disabilities in secondary schools. Five features define the Model Two high school program:

1. All basic skills are taught by a special educator and instruction in basic skills is linked to transition planning. Special education personnel would be responsible for teaching all English/reading and math courses required for graduation. These courses would not be simple modifications of the mainstream high school curriculum. Instead, the curriculum of these courses would address the functional skill needs of the students in the classes and be coordinated with the vocational education courses being taken by the students concurrently. Explicit discussions on the relevance of reading and math skills to vocational pursuits would be a regular part of the courses, as would discussions of job possibilities after completion of high school.

2. Required "content" subjects are taught by special educators. LD students with learning disabilities would not be scheduled to take science, social studies, or health in mainstream classes. Instead, these classes would be taught by special education personnel. Here, the curriculum would parallel the curriculum taught in basic content courses in the mainstream but would utilize text material written at a more readable level. Also, the course might cover some material less deeply and some material more deeply than the mainstream counterpart.

3. Vocational education is provided in the mainstream and coordinated with transition planning provided within special education. Beginning in the freshman year of high school, students would be scheduled into regular vocational education courses. The first 2 years of vocational courses would involve extensive exploration of job possibilities, including 
some on-the-job internships to "try on" various jobs, and would be scheduled for two periods per day. By the junior year, exposure to vocational/technical training would continue to occupy two periods per day, but vocational training would become more intense and involve sustained training in one occupation for 2 years. At the same time, vocational education teachers would work closely with special education personnel on skills students need to master the vocational content. These skills would be reinforced in the basic skills courses being taken by students concurrently. Also, special education and vocational education personnel would work with the students' counselors to be certain that coordinated transition planning is taking place.

4. All ninth grade students with learning disabilities will take a required course on survival skills taught by a special educator. A survival skills course would provide incoming ninth graders with an orientation to the rules and demands of high school and teach the students behavior control, teacherpleasing behaviors, and study skills expected of a high school student.

5. Students' schedules would reflect a light academic load in ninth grade to ensure successful completion of the first year of high school. During ninth grade, students would be scheduled to complete the two courses in art or humanities required for graduation. This would reduce the academic press of that first year in high school and increase the likelihood that students will have a successful year.

Figure 17 provides a summary of a 4-year high school program for LD students that meets basic requirements for graduation in the Commonwealth of Pennsylvania. Again, the schedule in Model Two assumes that students carry seven classes at a time.

Model Two would be especially suitable for students who enter high school with minimal competence in basic skills and who have no aspirations to attend college. It has several advantages:

1. Students with learning disabilities are sheltered from the demands of mainstream classes and are less likely to earn failing grades; if they earn passing grades in required courses, students are more likely to persist in school until graduation.

2. Required academic courses are distributed fairly evenly throughout the 4 years, and two additional courses in arts or humanities required for graduation are not scheduled until the junior and senior years so that ninth grade curriculum is not quite so formidable.

\begin{tabular}{|c|c|c|c|}
\hline Year 1 & Year 2 & Year 3 & Year 4 \\
\hline $\begin{array}{l}\text { English/ } \\
\text { Reading }^{*}\end{array}$ & $\begin{array}{l}\text { English/ } \\
\text { Reading* }\end{array}$ & $\begin{array}{l}\text { English/ } \\
\text { Reading* }\end{array}$ & $\begin{array}{l}\text { English/ } \\
\text { Reading }\end{array}$ \\
\hline Math* & Math* & Math* & \\
\hline $\begin{array}{l}\text { Social } \\
\text { Studies* }\end{array}$ & $\begin{array}{l}\text { Social } \\
\text { Studies* }\end{array}$ & & $\begin{array}{l}\text { Social } \\
\text { Studies* }\end{array}$ \\
\hline & Science* & Science $^{*}$ & Science* \\
\hline $\begin{array}{l}\text { Survival } \\
\text { Skills* }\end{array}$ & & & \\
\hline PE/Health* & PE & PE/Health* & $\mathrm{PE}$ \\
\hline Voc Ed & Voc Ed & Voc Ed & Voc Ed \\
\hline Voc Ed & Voc Ed & $\begin{array}{l}\text { Voc Ed } \\
\text { Elective }^{\star \star}\end{array}$ & $\begin{array}{l}\text { Voc Ed } \\
\text { Elective }^{\star \star}\end{array}$ \\
\hline
\end{tabular}

* Course taught by special education teacher.

** These courses would have to meet graduation requirements of two credits in Art and/or Humanities.

Note: This schedule meets Pennsylvania requirements for graduation.

\section{FIGURE 17}

\section{Four-Year Course Schedule for Students With Learning Disabilities in Model Two}

3. Students have at least two periods per day of more practical coursework with explicit future-oriented planning; if vocational education really does have holding power, vocational courses beginning as early as ninth grade should "hook" students who are at greatest risk for dropping out.

4. Students are likely to be interacting throughout the day with a smaller network of teachers and fellow students, creating a more personalized "school within a school" climate that also could function to hold students in school.

5. Students in Model Two will have been carefully prepared for the transition into the world of work or postsecondary job training and would have some immediately usable skills for entering the job market.

Although Model Two offers some distinct advantages for LD students, it will be difficult to implement well because of staffing problems, as well as state and local school policy constraints. There are two staffing issues to consider. First, given the enhanced role of special education personnel in the model, a high school adopting Model Two may have to increase the numbers of its special education staff. 
Second, special education teacher preparation programs simply do not prepare special education teachers as high school content subject specialists, so teachers will not be prepared for instructional duties in science, social studies, and health. We have observed secondary school content subject classes being taught by special educators; the teachers are so ill-at-ease with the subject matter that they cannot provide interesting elaborations or explanations of the content, and they cannot answer students' questions accurately. Students with learning disabilities who are in this model will be seriously shortchanged unless teacher preparation programs address this deficiency or school districts provide content updates for special education personnel given these new assignments.

Issues at the policy level also plague Model Two. First, graduation requirements set at the state level often consist of more than course titles. Curricula are defined for courses that will count toward meeting graduation requirements. Courses taught by special education personnel to LD students may, by design, deviate from the prescribed curriculum, to make them more relevant and more suitable to the students' skill and cognitive levels. A waiver may be required for these adapted courses to be counted toward high school graduation.

Second, a single high school may not have sufficient numbers of LD students to warrant offering the entire special education high school curriculum (four English courses, three math courses, three social studies courses, three science courses, and one health course) in a single year. Instead, social studies, science, and health courses may have to be offered on a rotating basis so that, over the course of four years, all courses will have been taught. This rotational system may make staffing easier, but LD students who transfer in or out of a given high school during the 4 years may have difficulty getting all the courses they need.

\section{CONCLUSIONS}

The secondary school is a complex environment that many students find difficult to negotiate. For LD students it presents formidable challenges. A poorly designed high school program can undermine students' self-concept and drive students from school before they are fully prepared. A well designed high school program provides opportunities to learn what has not yet been mastered, to develop social and interpersonal skills, to prepare for the world beyond public schooling.
An appropriate and effective secondary school program can fortify young people who have learning disabilities with the self-confidence and skills needed to function effectively in postsecondary education or employment, or in personal and social relationships. Our task is to organize schooling to provide opportunities for these things to happen regardless of the cost or how much change it requires of us. It is a challenging task, but it is a challenge we simply must meet.

I wish to acknowledge the support and cooperation of Dr. William Penn, Director of the Division for Exceptional Children, Pittsburgh Public Schools, without whom the work described in this article could not have been done. I also acknowledge grant support from OSEP through the divisions of Personnel Preparation Grants and Innovated Developments (directed and field-initiated research), whose funds made much of this work possible.

\section{REFERENCES}

Alexander, D. F. (1985). The effect of study skill training on learning disabled students retelling of expository material. Journal of Applied Behavior Analysis, 18, 263-267.

Alley, G., \& Deshler, D. (1979). Teaching the learning disabled adolescent: Strategies and methods. Denver: Love Publishing.

Association for Children and Adults with Learning Disabilities. (1982, September/October). ACLD vocational committee survey of learning disabled adults: Preliminary report. ACLD News Briefs, pp. $10-13$.

Bachman, J. G. (1972). Anti-dropout campaign and other misanthropies. Society, 9 .

Barrett, D. (1986). An analysis of policy variables relating to secondary learning disabled students who are mainstreamed into academic content areas. Unpublished doctoral dissertation, University of Pittsburgh.

Bradley, L., \& Bryant, P. (1985). Rhyme and reason in reading and spelling. Ann Arbor: University of Michigan Press.

Brown, G. M., Kerr, M. M., Zigmond, N., \& Harris, A. L. (1984). What's important for student success in high school? "Successful" and "unsuccessful" students discuss school survival skills. High School Journal, 68(1), 10-17.

Calfee, R. (1976). Sources of dependency in cognitive processes. In D. Klahr, Cognition and Instruction. New York: Erlbaum.

Cawley, J. F., Fitzmaurice-Hayes, A. M., \& Shaw, R. A. (1988). Mathematics for the mildly handicapped: A guide to curriculum and instruction. Boston: Allyn and Bacon.

Cawley, J. F., Fitzmaurice, A. M., Shaw, R. A., Kahn, H., \& Bates, H. III, (1978). Mathematics and learning disabled youth: The upper grade levels. Learning Disability Quarterly, 1, 37-52.

Cawley, J. F., Fitzmaurice, A. M., Shaw, R. A., Kahn, H., \& Bates, H. III, (1979a). LD youth and mathematics: A review of characteristics. Learning Disability Journal, 2, 29-44.

Cawley, J. F., Fitzmaurice, A. M., Shaw, R. A., Kahn, H., \& Bates, H. III, (1979b). Math word problems: Suggestions for LD students. Learning Disability Quarterly, 2, 25-41.

Cervantes, L. F. (1965). The dropout. Ann Arbor: University of Michigan Press. 
Cobb, R., \& Crump, W. (1984). Post-school status of young adults identified as learning disabled while enrolled in learning disabilities programs (Final report U.S.D.E. Grant No. G008302185). Tuscaloosa: University of Alabama.

Combs, J., \& Cooley, W. (1968). Dropouts in high school and after school. American Educational Research Journal, 5, 343-363.

Critchley, M. (1964). Developmental dyslexia. Springfield, IL: Charles C. Thomas.

Curley, T. J. (1971, March). The social system: Contributor or inhibitor to the school dropout (ED 049-344). Washington, DC: U.S. Dept. of Health, Education, and Welfare.

Cuthbertson, E. (1978). An analysis of secondary testing and grading procedures. Unpublished master's thesis, University of Kansas, Lawrence.

Dean, J. S. (1973, October). A plan to save dropouts: School-within-aschool. Clearing House, 48, 98-99.

deBettencourt, L., Zigmond, N., \& Thornton, H. S. (1989). Follow-up of post-secondary age rural learning disabled graduates and dropouts. Exceptional Children, 56(1), 40-49.

Deno, S. L., \& Mirkin, P. K. (1977). Data-based program modification: A manual. Reston, VA: Council for Exceptional Children.

Deshler, D. D., Lowrey, N., \& Alley, G. R. (1979). Preparing alternatives for LD adolescents: A nationwide survey. Academic Therapy, 14, 389-397.

Donahoe, K., \& Zigmond, N. (in press). High school grades of urban LD students and low achieving peers. Exceptionality.

Fardig, D., Algozzine, R., Schwartz, S., Hensel, J., \& Westling, D. (1985). Post-secondary vocational adjustment of rural, mildly handicapped students. Exceptional Children, 52(2), 115-121.

Fayne, H. R., \& Bryant, N. D. (1981). Relative effects of various word synthesis strategies on the phonics achievement of learning disabled youngsters. Journal of Learning Disabilities, 73, 616-623.

Fuchs, L. S., Hamlett, C. L., Fuchs, D., Stecker, P. M., \& Ferguson, C. (1988). Conducting curriculum-based measurement with computerized data collection: Effects of efficiency and teacher satisfaction. Journal of Special Education Technology, 9(2), 73-86.

Glass, G. G. (1978). Glass-analysis for decoding only. Garden City, NY: Easier to Learn, Inc.

Graden, J. L., Casey, A., \& Bonstrom, O. (1985). Implementing a prereferral intervention system: Part 2. The data. Exceptional Children, 51, 487-496.

Graham, S., \& Harris, K. R. (1989a). Cognitive training: Implications for written language. In J. Hughes \& R. Hall (Eds.), Cognitive behavioral psychology in the schools: A comprehensive handbook (pp. 247-279). New York: Guilford.

Graham, S., \& Harris, K. R. (1989b). Improving learning disabled students' skills at composing essays: Self-instructional strategy training. Exceptional Children, 56(3), 201-214.

Graham, S., \& Johnson, L. A. (1989). Teaching reading to learning disabled students: A review of research-supported procedures. Focus on Exceptional Children, 2l(6), 1-12.

Gregory, J. F., Shannahan, T., \& Walberg, H. (1986). A profile of learning disabled twelfth-graders in regular classes. Learning Disability Quarterly, 9(1), 33-42.

Hammontree, T. (1978, April). Profile of a dropout. Florida Vocational Journal, 3, 26-28.

Hartwell, L. K., Wiseman, D. E., \& Van Reusen, A. (1979). Modifying course content for mildly handicapped students at the secondary level. Teaching Exceptional Children, 12, 28-32.

Hasazi, S., Gordon, L., \& Roe, C. (1985). Factors associated with the employment status of handicapped youth exiting high school from 1979 to 1983. Exceptional Children, 51(6), 455-469.

Hewitt, J. D., \& Johnson, W. S. (1979, March). Dropping out in Middletown. High School Journal, 62, 252-256.
Hill, C. R. (1979, February). Capacities, opportunities, and educational investments: The case of the high school dropout. Review of Economics \& Statistics, 61, 9-20.

Hoffman, F. J., Sheldon, K. L., Minskoff, E. H., Sautter, S. W., Steidle, E. F., Baker, D. P., Bailey, M. B., \& Echols, L. D. (1987). Needs of learning disabled adults. Journal of Learning Disabilities, 20(1), 43-52.

Howell, F., \& Frese, W. (1982, Spring). Early transition into adult roles: Some antecedents and outcomes. American Educational Research Journal, 19(1), 51-73.

Howell, K., \& Morehead, M. K. (1987). Curriculum based evaluation in special and remedial education. Columbus, $\mathrm{OH}$ : Merrill Publishing Co.

Johnson, D. J., \& Myklebust, H. R. (1967). Learning disabilities. New York: Grune \& Stratton.

Johnson, D. W., \& Johnson, R. T. (1978). Cooperative, competitive, and individualistic learning. Journal of Research \& Development in Education, 12(1), 3-15

Kaplan, J., \& Luck, E. (1977, November). The dropout phenomenon as a social problem. Education Forum, 42, 41-56.

Kerr, M. M., Zigmond, N., Schaffer, A., \& Brown, G. (1986). An observational follow-up of successful and unsuccessful high school students. High School Journal, 70(1), 20-24.

Kowalski, C., \& Cangemi, J. (1974, November-December). High school dropouts-A lost resource. College Student Journal, 8, 71-74.

Kozol, J. (1985). Illiterate America. New York: Plume Publishers.

Laurie, T., Buchwach, L., Silverman, R., \& Zigmond, N. (1978). Teaching secondary learning disabled students in the mainstream, Learning Disability Quarterly, 1(4), 67-72.

Levin, E. K., Zigmond, N., \& Birch, J. W. (1985). A follow-up study of 52 learning disabled adolescents. Journal of Learning Disabilities, 18 , 2-7.

Lloyd, D. N. (1976, Winter). Concurrent prediction of dropout and grade of withdrawal. Educational \& Psychological Measurement, 36, 983-990.

Lloyd, J. W., \& Keller, C. E. (1989). Effective mathematics instruction: Development, instruction, and programs. Focus on Exceptional Children, 2l(7), 1-10.

Mahood, W. (1981, January). Born losers: School dropouts and pushouts. National Association of Secondary School Principals Bulletin, 65, 54-57.

Mare, R. D. (1980). Social background and school continuation decisions. Journal of American Statistical Association, 75, 195-305.

McKeown, M., \& Beck, I. (1988). Learning vocabulary: Different ways for different goals. Remedial \& Special Education, 9, 42-52.

Miller, S. E., Leinhardt, G., \& Zigmond, N. (1988). Influencing engagement through accommodation: An ethnographic study of atrisk students. American Educational Research Journal, 25(4), 465-488.

Moran, M. R. (1980). An investigation of the demands of oral language skills of learning disabled students in secondary classrooms (Research Report \#1). Lawrence: University of Kansas, Institute for Research in Learning Disabilities.

Morrow, D., Thornton, H., \& Zigmond, N. (1988). Graduation and postsecondary adjustment: Follow-up of urban-bound learning disabled students. Final Report. Pittsburgh: University of Pittsburgh.

National Commission on Excellence in Education. (1983). A nation at risk: The imperative for educational reform. Washington, DC: U.S. Dept. of Education.

Nickerson, R. S. (1985). Adult literacy and technology (Report No. 351). Champaign, IL: University of Illinois, Center for the Study of Reading. (ERIC Document Reproduction Service No. ED 266 420).

Norman, C.A., \& Zigmond, N. (1980). Characteristics of children labeled and served as learning disabled in school systems affiliated with child service demonstration centers. Journal of Learning Disabilities, $13,542-547$. 
O'Shea, L. J., Sindelar, P. T., \& O'Shea, D. J. (1987). The effects of repeated readings and attentional cues on the reading fluency and comprehension of learning disabled readers. Learning Disabilities Research, 2, 103-109.

Palinscar, A. S., \& Brown, A. L. (1984). Reciprocal teaching of comprehension-fostering and comprehension-monitoring activities. Cognition \& Instruction, 1, 117-175.

Polsgrove, L., \& McNeil, M. (1989). The consultation process: Research and practice. Remedial \& Special Education, 10(1), 6-13.

Riegel, R. H., \& Mathey, J. P. (1980). Mainstreaming at the secondary level: Seven models that work (Bulletin \#1427). Wayne County, MI: Intermediate School District.

Rumberger, R. W. (1983). Dropping out of high school: The influence of race, sex, and family background. American Educational Research Journal, 20(2), 199-220.

Rumberger, R. W. (1987). High school dropouts: A review of issues and evidence. Review of Educational Research, 57, 101-121.

Schalock, R. L., Wolzen, B., Ross, J., Elliott, B., Werbel, C., \& Peterson, J. (1986). Post-secondary community placement of handicapped students: A five year follow-up. Learning Disability Quarterly, 9(4), 295-303.

Schreiber, D. (1962). School dropouts. National Educational Association Journal, 51, 50-59.

Schumaker, J. B., Deshler, D. D., Alley, G. R., Warner, M. M., \& Denton, P. H. (1982). Multipass: A learning strategy for improving reading comprehension. Learning Disability Quarterly, 5, 295-304.

Silverman, R., Zigmond, N., \& Sansone, J. (1981). Teaching coping skills: A school survival skills curriculum for adolescents with learning disabilities. Focus on Exceptional Children, 13(6), 1-20.

Stoughton, C. R., \& Grady, B. R. (1978, Fall). How many students will drop out and why? North Central Association Quarterly, 53, 312-315.

Thornton, H. (1987). A follow-up study of learning disabled young adults who participated in mainstream vocational education programs. Unpublished doctoral dissertation, University of Pittsburgh.

Thornton, H., \& Zigmond, N. (1986). Follow-up of post-secondary age LD graduates and dropouts. LD Research, l(1), 50-55.

Thornton, H. S., \& Zigmond, N. (1987a, April). Predictors of dropout and unemployment among $L D$ high school youth: The holding power of secondary vocational education for $L D$ students. Paper presented at annual meeting of American Educational Research Association, Washington, DC.

Thornton, H. S., \& Zigmond, N. (1987b, April). Post-secondary follow-up of learning disabled and non-handicapped completers of mainstream vocational education programs. Paper presented at annual meeting of American Educational Research Association, Washington, DC.

Thornton, H. S., \& Zigmond, N. (1988). Secondary vocational training for LD students and its relationship to school completion status and post school outcomes. Illinois School Journal, 67(2), 37-54.

Tseng, M. S. (1972, July-August). Comparisons of selected personality and vocational variables of high school students and dropouts. Journal of Educational Research, 65, 462-466.

U. S. Department of Education. (1988). To assure the free appropriate public education of all handicapped children: Tenth annual report to Congress on the implementation of the Education of the Handicapped Act. Washington, DC: Government Printing Office.

U. S. Department of Education. (1989). To assure the free appropriate public education of all handicapped children: Eleventh annual report to Congress on the implementation of the Education of the Handicapped Act. Washington, DC: Government Printing Office.
Warner, M. M., Alley, G. R., Schumaker, J. B., Deshler, D. D., \& Clark, F. L. (1980). An epidemiological study of learning disabled adolescents in secondary schools: Achievement and ability, socioeconomic status, and school experiences (Research Report \#13). Lawrence: University of Kansas, Institute for Research in Learning Disabilities.

Weber, J., \& Silvani-Lacey (1983). Building basic skills: The dropout. Columbus: Ohio State University, National Center for Research in Vocational Education.

Wehlage, G. G., \& Rutter, R. A. (1986). Dropping out: How much does school contribute to the problem? Teachers College Record, 87, 374-392.

Wehlage, G. G., Rutter, R. A., Smith, G. A., Lesko, N., \& Fernandez, R. R. (1989). Reducing the risk: Schools as communities of support. New York: Falmer Press.

West, J. F., \& Idol, L. (1987). School consultation (Part 1): An interdisciplinary perspective on theory, models, and research. Journal of Learning Disabilities, 20, 388-408.

White, W., Schumaker, J., Warner, M., Alley, G., \& Deshler, D. (1980). The current status of young adults identified as learning disabled during their school career (Research Report \#21). Lawrence: University of Kansas, Institute for Research in Learning Disabilities.

Will, M. (1986). Educating students with learning problems: A shared responsibility. Washington, DC: Office of Special Education and Rehabilitative Services, U. S. Department of Education.

Williams, J. P. (1980). Teaching decoding with an emphasis on phoneme analysis and phoneme blending. Journal of Educational Psychology, 73, 697-704.

Wong, B. Y. L. (1986). Metacognition and special education: A review of a view. Journal of Special Education, 20(1), 9-29.

Zigmond, N. (1978). A prototype of comprehensive services for secondary students with learning disabilities. Learning Disability Quarterly, l(1), 39-49.

Zigmond, N. (1988, April). Evaluating staff development initiatives using direct observations of teacher and student behavior. Paper presented at annual meeting of American Educational Research Association, New Orleans.

Zigmond, N., Kerr, M. M., Brown, G. M., \& Harris, A. L. (1984). School survival skills in secondary school age special education students. Presented at annual meeting of the American Educational Research Association, New Orleans.

Zigmond, N., Kerr, M. M., \& Schaeffer, A. L. (1988). Behavior patterns of learning disabled adolescents in high school academic classes. Remedial \& Special Education, 9(2), 6-11.

Zigmond, N., Kerr, M. M., Schaeffer, A. L., Farra, H. E., \& Brown, G. M. (1986). The school survival skills curriculum. Pittsburgh: University of Pittsburgh.

Zigmond, N., Levin, E., \& Laurie, T. E. (1985). Managing the mainstream: An analysis for teacher attitudes and student performance in mainstream high school programs. Journal of Learning Disabilities, 18(9), 535-541.

Zigmond, N., \& Thornton, H. S. (1985). Follow-up of post-secondary age LD graduates and dropouts. Learning Disabilities Research, I(1), $50-55$.

Zigmond, N., \& Thornton, H. (1988)). Learning disabilities in adolescents and adults. In K. Kavale (Ed.), Learning disabilities: State of the art and practice. San Diego: College Hill Press. 


\section{NEW}

\section{Free Appropriate Public Education}

The Law and Children with Disabilities

Third Edition

\section{H. Rutherford Turnbull III}

\section{University of Kansas}

This book is the answer for those that want information on significant legislation regarding the handicapped. Laws are discussed with attention to their impact on the child, the parents, the tic schools, and higher education.

This definitive resource covers legislation, case law techniques, statutory techniques, due process, parent participation and more. Over 500 cases are cited and a helpful glossary explains the legal terminology. This new work is upto-date and includes material on AIDS and the Timothy $W$. case. It belongs on the desk of every professional educator and should be a resource for any course dealing with law and the handicapped. Hearing officers should have this book.

It is new and accurate. You'll want it on your desk today.

\section{Contents:}

Part One

Introduction to the Law

1 Introduction to the American Legal System

2 Introduction to Law and Free Appropriate Public Education

\section{Part Two}

The Six Major Principles

3 Zero Reject

4 Testing, Classification, and Placement

5 Individualized and Appropriate Education

6 Least Restrictive Appropriate Educational Placement

7 Procedural Due Process

8 Parent Participation and Shared Decision Making

\section{Part Three}

Enforcing the Law

9 Case Law Techniques

10 Statutory Techniques

\section{Part Four}

Free Appropriate Public Education and the American Value System

11 Objections to the EHA and Answers to Them

12 Underlying Beliefs and Values in Right-to-Education Laws

\section{FREE APPROPRIATE PUBLIC EDUCAIION}

\section{The Law and \\ children with \\ Disabilities \\ Third Edition}

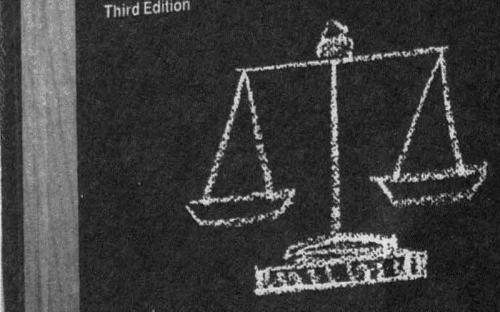

H. Rutherford Turnbull III

9-9004/hardback/ISBN ()-8.910)-211-5

$\$ 39.95$ 


\section{Professional update}

\section{October 4-6, 1990}

International Council for Learning Disabilities Radisson Plaza Hotel

Austin, TX

Contact: CLD, (913) 492-8755

\section{October 18-20, 1990}

Symposium on Culturally Diverse Exceptional Children Albuquerque Marriott Hotel

Albuquerque, NM

Contact: CEC, (703) 620-3660

\section{October 20-23, 1990}

Division for Exceptional Children-CEC International Early Childhood Conference Albuquerque Convention Center Albuquerque, NM

Contact: CEC, (703) 620-3660
November 14-18, 1990

National Association for Gifted Children Excelsior Hotel

Little Rock, AR

Contact: NAGC, (202) 785-4268

\section{December 6-8, 1990}

Association for Persons with Severe Handicaps Palmer House Hotel

Chicago, IL

Contact: TASH, (206) 523-8446

\section{April 1-5, 1991}

Council for Exceptional Children

Annual Convention

Atlanta, GA

Contact: CEC, (703) 620-3660 